\title{
The Dessau Grassland Experiment-Impact of Fertilization on Forage Quality and Species Assembly in a Species-Rich Alluvial Meadow
}

\author{
Sandra Dullau ${ }^{1, * \mathbb{D}}$, Knut Rydgren ${ }^{2}$, Anita Kirmer ${ }^{1}{ }^{(\mathbb{D}}$, Urs Georg Jäger ${ }^{3}$, Maren Helen Meyer ${ }^{1}$ \\ and Sabine Tischew ${ }^{1}$
}

check for

updates

Citation: Dullau, S.; Rydgren, K.; Kirmer, A.; Jäger, U.G.; Meyer, M.H.; Tischew, S. The Dessau Grassland Experiment-Impact of Fertilization on Forage Quality and Species Assembly in a Species-Rich Alluvial Meadow. Agriculture 2021, 11, 339. https://doi.org/10.3390/ agriculture11040339

Academic Editor: Michele Scotton

Received: 10 March 2021

Accepted: 6 April 2021

Published: 9 April 2021

Publisher's Note: MDPI stays neutral with regard to jurisdictional claims in published maps and institutional affiliations.

Copyright: (c) 2021 by the authors. Licensee MDPI, Basel, Switzerland. This article is an open access article distributed under the terms and conditions of the Creative Commons Attribution (CC BY) license (https:/ / creativecommons.org/licenses/by/ $4.0 /)$.
1 Department of Agriculture, Oecotrophology and Landscape Development, Anhalt University of Applied Sciences, 06406 Bernburg, Germany; anita.kirmer@hs-anhalt.de (A.K.); maren.meyer@hs-anhalt.de (M.H.M.); sabine.tischew@hs-anhalt.de (S.T.)

2 Department of Environmental Sciences, Western Norway University of Applied Sciences, 6851 Sogndal, Norway; knut.rydgren@hvl.no

3 Department of Nature Conservation, State Office for Environmental Protection Saxony-Anhalt, 06116 Halle (Saale), Germany; Urs.Jaeger@lau.mlu.sachsen-anhalt.de

* Correspondence: sandra.dullau@hs-anhalt.de; Tel.: +49-3471-3551228

\begin{abstract}
Since alluvial meadows of river valleys of the Cnidion dubii are protected by the EU Habitats Directive, reconciling farmers' demands for forage quality with the objective of maintaining them in good conservation status is an important issue in grassland research. In a long-term experiment from 2010 to 2018, we investigated the impact of fertilizing on forage quality and species assembly on a species-rich and twice-mown alluvial grassland in the Dessau Elbe floodplain (Germany). The experiment was composed of an unfertilized control, PK, N60, N60PK and N120PK applications. A significant improvement in forage quality was achieved by nitrogen fertilization only for crude protein, with higher feeding requirements for sheep met only in individual years. The legume cycle was inhibited by the application of nitrogen and high grass cover was maintained, but not increased, at the highest nitrogen application after an exceptional summer flood. The target forbs persisted in numbers over the study period in all treatments. For cover, the low-competitive target forbs responded neutrally to nitrogen fertilization, whereas detrimental effects were demonstrated for the competitive ones. Thus, we recommend not applying more than $60 \mathrm{~kg} \mathrm{year}^{-1}$ of nitrogen and only in combination with phosphorus and potassium.
\end{abstract}

Keywords: alluvial grassland; fertilizer levels; feeding value; legume cycle; target forbs

\section{Introduction}

In Europe, grasslands play an important role as part of agricultural production systems [1,2]. Grasslands have been acknowledged to simultaneously provide multiple ecosystem functions and services [3-6], such as feed base for livestock [7,8], pollination services [9] and as an important contribution to biodiversity [10]. Due to the drastic decline of grassland area during the last century [11-13], many grassland types have been protected by the EU Habitats Directive and deterioration must be avoided [14,15]. The grassland habitat type 6440, alluvial meadows of river valleys of the Cnidion dubii, occurs in central to southeastern Europe, with a distribution focus in the large German floodplains. Within Natura 2000 sites, alluvial meadows occur in Germany on an estimated 3732 ha [16]. In the northern German floodplain regions, a tremendous change in the composition of plant communities has occurred over the last 50 years, with a consistent trend towards species-poor communities caused by agricultural intensification, and in particular nutrient input [12]. This situation also applies to Germany's other floodplain regions [17-19]. Therefore, the national conservation status of alluvial meadows is currently ranked as unfavorable-bad $[20,21]$. Nevertheless, particularly in areas not subject to intensive dairy 
farming, species-rich alluvial meadows can still be found in a good conservation status. In the Dessau Elbe floodplain, a large part of the grassland belongs to habitat type 6440 . Many farms participate in agri-environmental schemes and mow twice a year, which is in accordance with the habitat type management recommendations for mowing frequency [16]. Due to species composition and mowing time, the grassland biomass is less suitable for dairy cattle [22] and is mainly used as hay for feeding sheep, robust cattle and horses. Therefore, the interest in nature conservation is often in conflict with the demand of regional farmers to fertilize species-rich grasslands in order to improve forage quality.

Currently, there are few long-term studies on the development of forage quality in permanent grasslands [23-26]. In many cases, only results from one- to three-year experimental studies have been published [27-30], or the quantity and quality of forage production of different meadow types have been evaluated [31,32].

There are also few long-term studies on changes in the species assembly of speciesrich alluvial meadows that have been subjected to different fertilization treatments. Three studies on alluvial Alopecurus pratensis L. meadows are unique: the Černíkovice experiment in the center of the Czech Republic [33,34], the Vel'ká Lúka experiment in the center of Slovakia [35] and the Steinach experiment in SE Germany (Bavaria) [36]. These studies compared the effect of different fertilizer applications only after decades of use, while annual fluctuations and periodic oscillations were not evaluated. However, consideration of these aspects is important to improve our understanding of the relationships between fertilization, forage quality and species assembly.

Starting from a species-rich condition, studies from mountain and alpine regions showed drastic changes in species assembly and reduced nature conservation value due to nitrogen fertilization $[31,37]$. For lowland and mountain meadows, the promotion of grasses and the decrease of legumes by nitrogen application have been described prominently $[30,38,39]$. Legumes have a positive effect on forage quality [40-42] and are in a periodic system in grassland $[43,44]$. The legume cycle and the effects of fertilization have hardly been studied so far [44], and to our knowledge, have not been investigated for grasslands with flooding events. Finally, the change in alluvial meadow target species is also an important issue. It has been commonly found that nitrogen fertilization led to decreased plant species richness for the whole range of European grassland types [45]. In addition, target species numbers are expected to decrease [46-52]. There are different findings on the response of grassland forbs to fertilization [53-55]. Of interest here is the effect of plant strategy types on target forbs performance, assuming that low-competitive forbs will benefit if no nitrogen fertilizer is applied due to reduced light competition [56,57].

Based on the results of previous grassland studies on the effect of fertilization, there is a certain discrepancy between the demand for improving forage quality through fertilization and the conservation of species assembly in species-rich floodplain grassland. In a largescale field experiment, we examined the effects of different fertilization treatments on the development of forage quality and species assembly of a species-rich alluvial meadow over eight years. We focused on the following questions: (Q1) Can forage quality be increased by fertilization to the extent that it is suitable for higher performance phases of sheep? (Q2) Which fertilization treatments have a negative influence on target species number development? (Q3) How does the grass and legume cover change with different fertilizer applications? (Q4) Do low-competitive and competitive target forbs respond similarly to different fertilizer applications? We discuss our findings in a wider perspective, the challenge to reconcile farmers' demands on the forage quality of alluvial grasslands with the nature conservation goal of maintaining them in good conservation status.

\section{Materials and Methods}

\subsection{Study Area}

Our study area is situated on the Elbe floodplain near Dessau in Saxony-Anhalt (N $51^{\circ} 5^{\prime} 09.35^{\prime \prime}, \mathrm{E} 12^{\circ} 17^{\prime} 57.12^{\prime \prime}, 58 \mathrm{~m}$ above sea level). The climate is continental with a mean annual precipitation of $571 \mathrm{~mm}$ and a mean annual temperature of $9.4{ }^{\circ} \mathrm{C}$ (long- 
term mean 1981-2010, Deutscher Wetterdienst). The Elbe River is $2.5 \mathrm{~km}$ away and used to flood the area in spring, but during the study period, the study site was not flooded every year. Dry soil conditions prevail in summer. The soil is an acidic gley, characterized by low phosphorus and a medium potassium level. The grassland belongs to the Natura 2000 habitat type 6440 (alluvial meadows of river valleys of the Cnidion dubii), protected by the Habitats Directive 92/43/EEC, and to the plant association Sanguisorbo officinalis-Silaetum silai Klapp 1951, a vegetation type with low fodder value [58]. Before the experiment started, the permanent and never oversown grassland was in a favorable conservation status. Species richness was high with a mean number of vascular plants of $30.0( \pm 3.4)$ and forbs of $23.8( \pm 2.9)$ on $25 \mathrm{~m}^{2}$. The study site contains the characteristic river corridor plants (according to Burkart [59]) Allium angulosum L., Carex praecox Schreb., Galium boreale L., Sanguisorba officinalis L., Selinum dubium (Schkuhr) Leute, Silaum silaus (L.) Schinz \& Thell., Thalictrum flavum L., Veronica maritima L. and Viola stagnina Kit. ex Schult. Other frequently occurring species are Anthoxanthum odoratum L., Daucus carota L., Euphorbia esula L., Galium album Mill., Lathyrus pratensis L., Leucanthemum ircutianum Turcz. ex DC., Lychnis flos-cuculi L., Poa angustifolia L., Ranunculus acris L., Rumex acetosa L., Scorzoneroides autumnalis (L.) Moench and Trifolium pratense L. The dominant grass was Alopecurus pratensis. The nomenclature of vascular plants follows Jäger [60].

The meadow was traditionally mown twice in the growing season for hay making, and, depending on the growth, additionally grazed by sheep in autumn and not fertilized for at least 30 years. During the experiment, an exceptional flooding event flooded the area for six weeks in summer 2013 and destroyed all vegetation. However, the vegetation recovered within a few weeks and only the less flood-tolerant species Festuca pratensis Huds. declined sharply.

\subsection{Experimental Design and Sampling}

In 2010, the experiment was established in four completely randomized blocks with each block containing five square sample plots $(5.0 \times 5.0 \mathrm{~m})$ each for one of the five treatments. The meadow was mown twice, with a first cut in early June and a second cut mid-August. The fertilizer treatments were: (i) unfertilized control (N0), (ii) phosphorus and potassium as withdrawn (PK), (iii) nitrogen $60 \mathrm{~kg} \mathrm{ha}^{-1}$ year $^{-1}$ (N60), (iv) nitrogen $60 \mathrm{~kg} \mathrm{ha}^{-1}$ year $^{-1}$ plus phosphorus and potassium as withdrawn (N60PK) and (v) nitrogen $120 \mathrm{~kg} \mathrm{ha}^{-1}$ year $^{-1}$ plus phosphorus and potassium as withdrawn (N120PK). The phosphorus and potassium content of the biomass was determined together with measurement of the forage quality parameters. Both nutrients were applied in the amounts that were removed with the harvest in the previous year, calculated for each treatment. We used mineral fertilizer applied in commercially available granules, nitrogen as urea in two doses before and shortly after the first cut, phosphorus in the form of triple superphosphate and potassium in the form of 60er Kali in one dose before the first cut.

Soil samples were taken at the plot level at a depth of $0-10 \mathrm{~cm}$ (mixing of 10 soil core samples per plot), in March 2010 to 2015 and 2017. Overall, the soil had a pH of $4.88( \pm 0.17)$ (analyzed after DIN [61]), contained $0.47 \%( \pm 0.11)$ total nitrogen (analyzed after DIN [62]) and $5.73 \%( \pm 1.11)$ total carbon (analyzed after DIN [63]). Plant-available phosphorus (double-lactate method) was measured at a very low level $(14.6 \mathrm{mg} \mathrm{kg} \pm 6.9)$ and potassium at an optimal level (127.0 mg kg \pm 35.9 ) (both analyzed after VDLUFA [64], classification of nutrient concentration level after LLG [65]. The soil chemical characteristics before the start of the experiment in 2010 are shown in Table 1. Despite different fertilization treatments, the soil characteristics did not differ between the treatments over time (Figure A1).

We recorded vascular plant species abundance from 2010 to 2018 (except in 2016) using the Londo scale [66] on the $5.0 \times 5.0 \mathrm{~m}$ plots annually in mid-May. The estimation of the percentage contribution of Cirsium arvense $\mathrm{L}$. to the aboveground plant biomass (yield proportion: Voigtländer and Voss [67]) was made on the $5.0 \mathrm{~m} \times 5.0 \mathrm{~m}$ plots shortly before the first and second cuts. 
From 2010 to 2017 (except 2013, 2016), we cut all plants within one randomly selected $1 \mathrm{~m}^{2}$ frame in each plot at a height of 3-5 cm shortly before mowing to estimate forage quality. Samples were dried and analyzed in a laboratory by near-infrared reflectance spectroscopy (NIRS) according to standard VDLUFA [68] methods for the concentrations of crude protein and crude fiber in the dry matter (DM). Metabolizable energy was calculated according to Losand et al. [69] (with cellulase solubility ELOS and acid detergent fiber ADF determined by NIRS). The NIRS method was used due to the high number of samples (40 per year) to reduce costs.

Table 1. Mean and standard deviation (in brackets) of soil chemical characteristics (sampling depth $0-10 \mathrm{~cm}$ ) before the experiment started.

\begin{tabular}{cccccc}
\hline Treatment & pH Value & $\begin{array}{c}\text { Phosphorus } \\
\text { (mg kg) }\end{array}$ & $\begin{array}{c}\text { Potassium } \\
\text { (mg kg) }\end{array}$ & $\begin{array}{c}\text { Total Carbon } \\
(\mathbf{\%})\end{array}$ & $\begin{array}{c}\text { Total } \\
\text { Nitrogen (\%) }\end{array}$ \\
\hline N0 & $4.84(0.14)$ & $9.50(2.65)$ & $105.00(20.90)$ & $5.23(0.91)$ & $0.46(0.10)$ \\
PK & $4.92(0.14)$ & $13.75(6.24)$ & $111.50(21.08)$ & $5.43(1.23)$ & $0.48(0.12)$ \\
N60 & $4.84(0.14)$ & $10.75(6.24)$ & $121.75(19.05)$ & $5.80(1.33)$ & $0.50(0.13)$ \\
N60PK & $4.96(0.05)$ & $13.50(7.77)$ & $126.25(18.87)$ & $5.48(0.71)$ & $0.47(0.08)$ \\
N120PK & $4.83(0.17)$ & $10.50(0.58)$ & $127.25(17.91)$ & $5.90(0.80)$ & $0.50(0.08)$ \\
\hline
\end{tabular}

\subsection{Species Groups}

The species group of grasses included all species of the plant families Poaceae, Cyperaceae and Juncaceae. Legumes are species of the plant family Fabaceae. Target species are characteristic species of habitat type 6440 [70] and characteristic species and other low growing forbs of the Sanguisorbo officinalis-Silaetum silai [58]. High-competitive target forbs are species of the ecological strategy types C and CS (after Grime et al. [71]).

\subsection{Statistical Analyses}

All statistical analyses were performed in $\mathrm{R}$ version 4.0.4 [72].

We modelled the soil variables, the forage quality variables $(\mathrm{Q} 1)$, the target species number $(\mathrm{Q} 2)$ and the cover variables $(\mathrm{Q} 3, \mathrm{Q} 4)$ as functions of fertilization treatments and time with generalized linear mixed models (GLMMs; [73]). All soil variables, i.e., $\mathrm{pH}$, phosphorus, potassium, total carbon and total nitrogen; and forage quality variables, i.e., crude protein, crude fiber and metabolizable energy, were modelled with identity-link and Gaussian errors. The cover of grasses, legumes and all target forbs, as well as of low- and high-competitive target forbs, were expressed as percentages, that is as strictly bounded but non-binomial data. We therefore logit-transformed these variables [74] before modelling them with identity-link and Gaussian errors. The target species number was modelled with log-link and Poisson errors.

All models were parameterized using the R package LME4, version 1.1.26 [73], accounting for repeated measurements and the spatially nested sampling structure by specifying plot nested within block as random (intercept) effects in the models. For four of the models, i.e., crude protein (first cut), cover of all target forbs, cover of high-competitive target forbs and the target species number, the mixed-effects model was singular. For the first three models, we used a simpler model with only one random effect with accounting for the repeated measurements but not for the target species number; the model was still singular. Therefore, we used generalized linear model without random effects for target species number. Thus, all these three models therefore needed to be interpreted more conservatively. We simplified the models as much as possible to find the minimal adequate model by using a backward selection procedure with likelihood ratio tests [75].

\section{Results}

\subsection{Forage Quality}

At the beginning of the experiment in 2010, crude fiber concentration in all treatments was higher for the first cut than for the second cut. Crude protein concentrations and the 
values for metabolizable energy showed the opposite (Table A1). For all forage quality parameters, the range of variation occurring during the study period was always higher for the second cut than for the first cut (Table 2). The raw data are provided in Table S1.

Table 2. Forage quality shown as minimum and maximum yearly means of the six sampling years for the first and second cuts. The raw data are provided as a Supplementary File (Table S1).

\begin{tabular}{lcccccc}
\hline & & N0 & PK & N60 & N60PK & N120PK \\
\hline Crude fiber & First cut & $257-295$ & $259-289$ & $257-293$ & $258-307$ & $268-308$ \\
$\left(\mathrm{~g} \mathrm{~kg} \mathrm{DM}^{-1}\right)$ & Second cut & $242-291$ & $241-297$ & $228-288$ & $237-293$ & $250-320$ \\
\hline Crude protein & First cut & $90-110$ & $92-101$ & $96-121$ & $94-126$ & $104-131$ \\
$\left(\mathrm{~g} \mathrm{~kg} \mathrm{DM}^{-1}\right)$ & Second cut & $102-124$ & $94-120$ & $105-132$ & $105-142$ & $98-150$ \\
\hline Metabolizable energy & First cut & $8.5-9.5$ & $8.5-9.5$ & $8.7-9.5$ & $8.4-9.4$ & $8.4-9.3$ \\
$\left(\mathrm{MJ} \mathrm{kg} \mathrm{DM}^{-1}\right)$ & Second cut & $8.1-9.6$ & $7.9-10.1$ & $8.1-9.9$ & $7.8-10.0$ & $7.6-9.4$ \\
\hline
\end{tabular}

Crude protein showed significant differences between the three treatment groups obtained as minimal adequate model, N0 \& PK, N60 \& N60PK and 120PK (Figure 1), for both the first and second cuts, and these groups also had a different development over time (Table 3, Figure 1). The crude protein concentration of the treatment group N0 \& PK remained at similar levels throughout the study period at both cuts, while the nitrogenfertilized treatment groups, N60 \& N60PK and N120PK, changed significantly more over time. For the first cut, the crude protein concentration increased from the third year of the experiment and was particularly high in the years 2014 and 2015, after the summer flood in 2013. The largest increase was observed for the N120PK treatment in the 2014-2015 period (Figure 1). For the second cut, crude protein contents of the nitrogen-fertilized treatments peaked in 2014, after the summer flood of 2013, before decreasing continuously in the following years. In particular, the N120PK treatment had a strong decrease in these years (Figure 1).

Table 3. Effects of fertilizer and year on the crude protein of the first cut in early June and the second cut in mid-August according to the minimal adequate model. Both models had three levels for the fertilizer, for the first cut four levels for year, and for the second cut five levels for year (Figure 1).

\begin{tabular}{lcccccc}
\hline & Sum Sq & Mean Sq & NumDF & DenDF & F value & $p$ \\
\hline First cut & & & & & & \\
\hline Fertilizer & 2385.9 & 1192.9 & 2 & 19.6 & 15.1 & $<0.001$ \\
Year & 5736.8 & 1912.3 & 3 & 91.0 & 24.1 & $<0.001$ \\
Fertilizer $\times$ Year & 1947.3 & 324.6 & 6 & 91.0 & 4.1 & 0.001 \\
\hline Second cut & & & & & & \\
\hline Fertilizer & 2538.6 & 1269.3 & 2 & 15.7 & 10.6 & 0.001 \\
Year & 9408.6 & 2352.2 & 4 & 87.3 & 19.6 & $<0.001$ \\
Fertilizer $\times$ Year & 5255.9 & 657.0 & 8 & 87.3 & 5.5 & $<0.001$ \\
\hline
\end{tabular}

For the first cut, crude fiber (Table 4, Figure 2a) and metabolizable energy (Table 5, Figure 3a) did not develop differently over time in the fertilizer treatments. In contrast, for the second cut, the two treatment groups, N0 \& PK \& N60 \& N60PK and N120PK, developed significantly differently over time for crude fiber (Table 4) and metabolizable energy (Table 5). For crude fiber, both treatment groups increased from 2010 to the 2011, 2012 and 2014 period before they decreased in 2015 and then increased again in 2017, and in particular in the N120PK treatment (Figure 2b). Metabolizable energy decreased from 2010 to 2011 before increasing in the 2012 to 2015 period (Figure 3b). In 2014, the year after the summer flood, metabolizable energy showed the lowest concentration. While metabolizable energy in the N0 \& PK \& N60 \& N60PK treatment group increased again at the end of the study period in 2017, the N120PK treatment differed and returned to the low 2014 level (Figure 3b). 
(a)

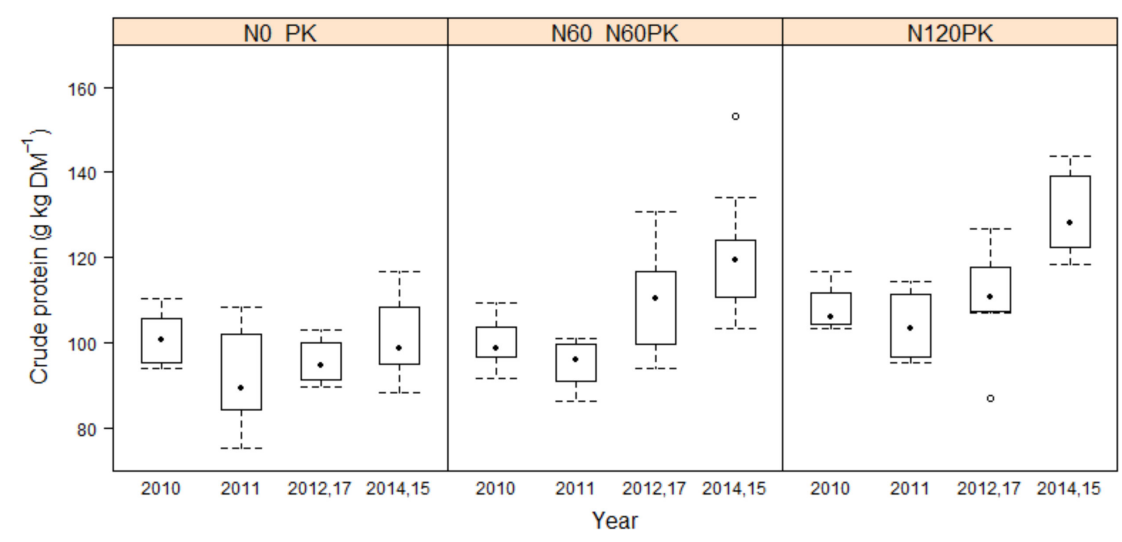

(b)

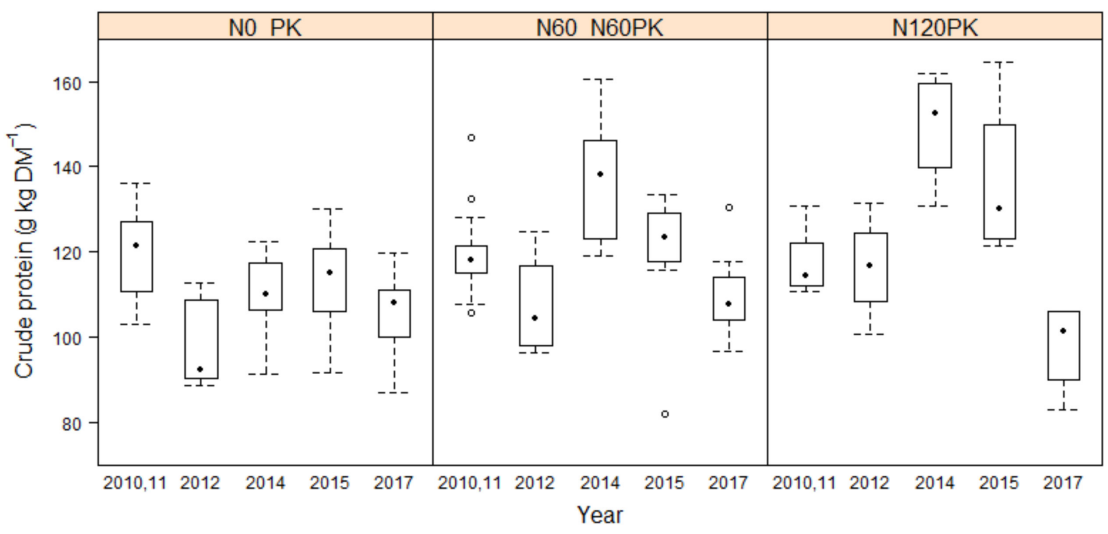

Figure 1. The minimal adequate model for the effect of fertilization treatment and time on the concentration of crude protein $\left(\mathrm{g} \mathrm{kg} \mathrm{DM}^{-1}\right)$ for the first (a) and second (b) cuts with different fertilization treatments between 2010 and 2017 (except 2013 and 2016). Level needed for female sheep (70-100 kg): $72-73 \mathrm{~g} \mathrm{~kg} \mathrm{DM}^{-1}$, for ewes (70-100 kg) rearing a single lamb: 122-143 $\mathrm{g} \mathrm{kg} \mathrm{DM}^{-1}$, for rams 100-120 kg: $75 \mathrm{~g} \mathrm{~kg} \mathrm{DM}^{-1}$, for rams in the breeding season: $140 \mathrm{~g} \mathrm{~kg} \mathrm{DM}^{-1}$ [76].

Table 4. Effects of fertilizer and year on the crude fiber of the first cut in early June and the second cut in mid-August according to the minimal adequate model. Both models had two levels for the fertilizer and four levels for year (Figure 2).

\begin{tabular}{lcccccc}
\hline & Sum Sq & Mean Sq & NumDF & DenDF & F value & $p$ \\
\hline First cut & & & & & & \\
\hline Fertilizer & 2348.9 & 2348.9 & 1 & 15 & 17.0 & $<0.001$ \\
Year & $21,407.3$ & 7135.8 & 3 & 97 & 51.7 & $<0.001$ \\
\hline Second cut & & & & & & \\
\hline Fertilizer & 1702.5 & 1702.5 & 1 & 23.9 & 5.9 & 0.023 \\
Year & $24,466.3$ & 8155.4 & 3 & 94.4 & 28.3 & $<0.001$ \\
Fertilizer $\times$ Year & 6627.1 & 2209.0 & 3 & 94.4 & 7.7 & $<0.001$ \\
\hline
\end{tabular}


(a)

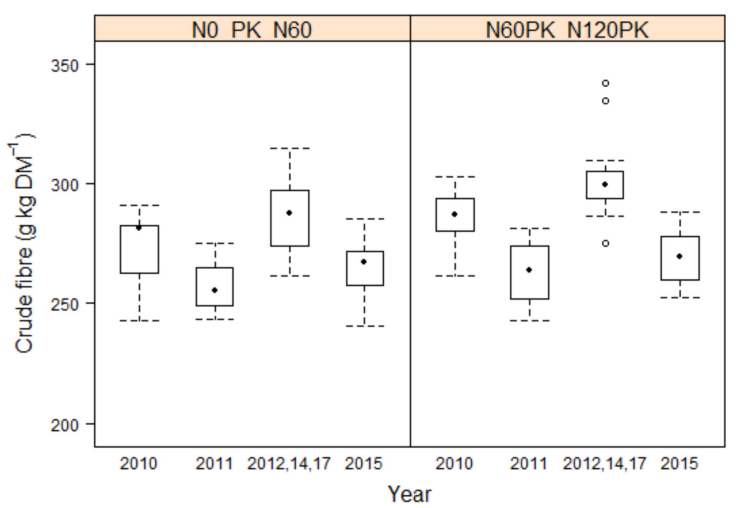

(b)

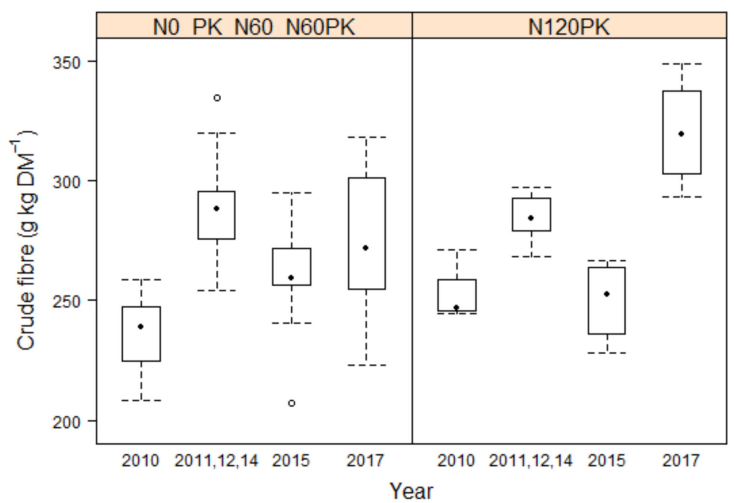

Figure 2. The minimal adequate model for the effect of fertilization treatment and time on the concentration of crude fiber ( $\mathrm{g} \mathrm{kg} \mathrm{DM}^{-1}$ ) for the first (a) and second (b) cuts with different fertilization treatments between 2010 and 2017 (except 2013 and 2016).

Table 5. Effects of fertilizer and year on the metabolizable energy of the first cut in early June and the second cut in mid-August according to the minimal adequate model. Both models had two levels for the fertilizer and five levels for year (Figure 3).

\begin{tabular}{lcccccc}
\hline & Sum Sq & Mean Sq & NumDF & DenDF & F Value & $p$ \\
\hline First cut & & & & & & \\
\hline Fertilizer & 0.6 & 0.6 & 1 & 15 & 8.8 & 0.01 \\
Year & 10.6 & 2.7 & 4 & 96 & 35.8 & $<0.001$ \\
\hline Second cut & & & & & & \\
\hline Fertilizer & 1.8 & 1.8 & 1 & 18.6 & 12.6 & 0.022 \\
Year & 28.0 & 7.0 & 4 & 92.2 & 48.2 & $<0.001$ \\
Fertilizer $\times$ Year & 2.9 & 0.7 & 4 & 92.2 & 5.0 & 0.001 \\
\hline
\end{tabular}

(a)

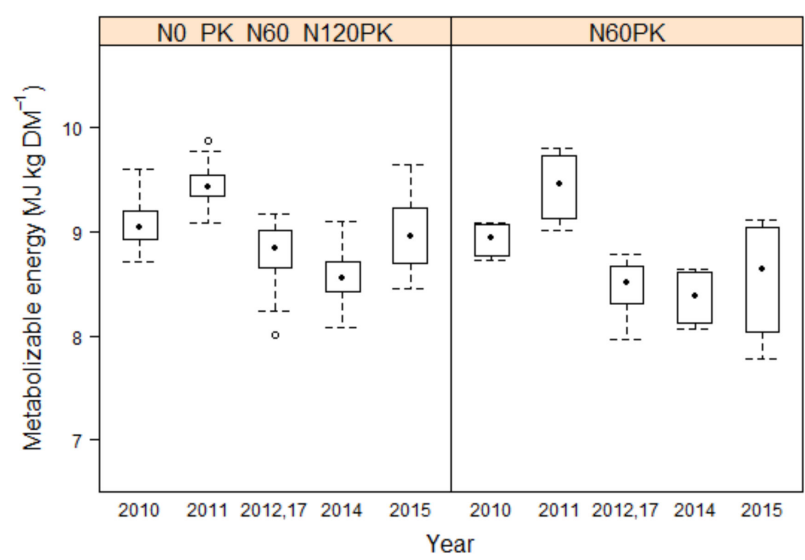

(b)

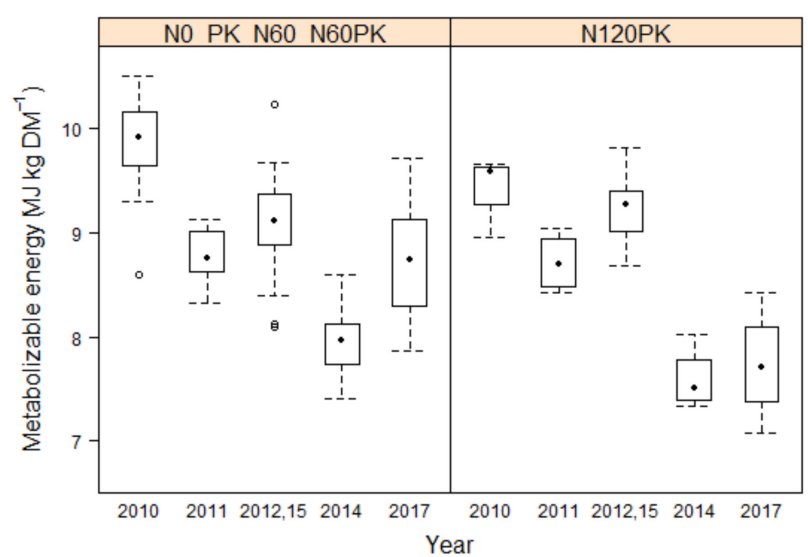

Figure 3. The minimal adequate model for the effect of fertilization treatment and time on the metabolizable energy $\left(\mathrm{MJ} \mathrm{kg} \mathrm{DM}^{-1}\right.$ ) for the first (a) and second (b) cuts with different fertilization treatments between 2010 and 2017 (except 2013 and 2016). Level needed for female sheep (70-100 kg): 8.7-8.8 $\mathrm{MJ} \mathrm{kg} \mathrm{DM}^{-1}$, for ewes (70-100 kg) rearing a single lamb: 10.4-10.7 MJ kg DM ${ }^{-1}$, for rams 100-120 kg: 9.4 MJ kg DM ${ }^{-1}$, for rams in the breeding season: $10.0 \mathrm{MJ} \mathrm{kg} \mathrm{DM}^{-1}$ [76]. 
Summarizing for the second cut, at the end of the study period in 2017, the forage value of the N120PK treatment was the lowest due to low crude protein and metabolizable energy concentrations and the highest crude fiber concentration. This development was accompanied by the strongest increase in the yield proportion of Cirsium arvense in 2017 (Figure A2).

\subsection{Species Assembly}

\subsubsection{Development of Target Species Number}

Almost two-thirds of the species were target species, of which 28 were forbs (including four legumes) and eleven were grasses (Table A2). In the observation period, mean target species number did not differ significantly between treatments or years, and neither did the treatments differ over time (Figure 4). The target species persisted despite high nitrogen application over the 8-year study period.

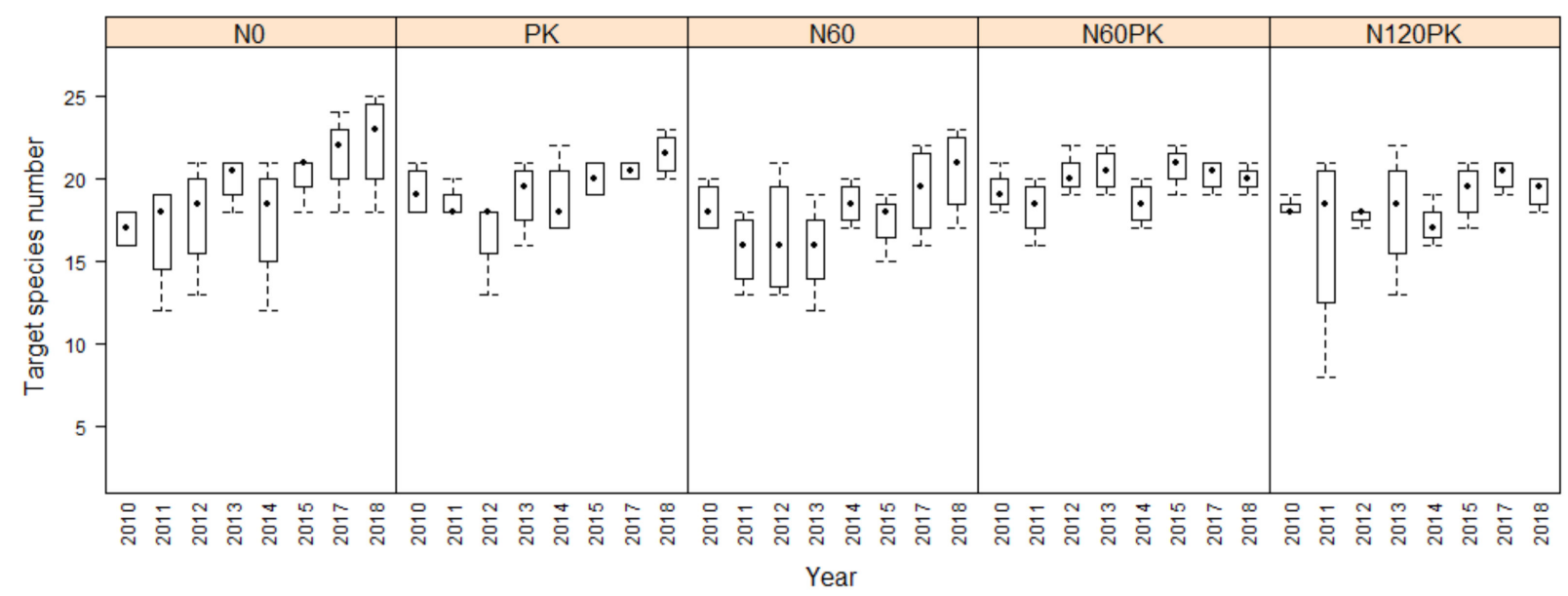

Figure 4. Development of the number of target species with different fertilization treatments between 2010 and 2018 (except 2016). There were no significant differences between treatments or years according to the generalized linear model (GLM).

\subsubsection{Development of Grass Cover}

The grass cover developed differently over time for the three treatment groups N0 \& PK, N60 and N60PK \& N120PK (Table 6). For the N0 \& PK and the N60 group it decreased considerably over time from 2014 onwards and stabilized at a low level in the years 20172018 (Figure 5). The N60PK \& N120PK treatments were less affected by the flooding, showing a smaller decline in grass cover. After the flood in 2013, Festuca pratensis declined sharply and remained at very low levels in all plots, regardless of whether fertilizer was applied (Figure A3). By 2017-2018, grass cover in nitrogen-fertilized plots recovered almost to the baseline level as Alopecurus pratensis and, especially for N120PK, Elymus repens (L.) Gould increased in cover (Figure A3).

Table 6. Effects of fertilizer and year on the cumulative cover of grasses according to the minimal adequate model. The model had three levels for the fertilizer and three levels for year (Figure 5).

\begin{tabular}{lcccccc}
\hline & Sum Sq & Mean Sq & NumDF & DenDF & F Value & $p$ \\
\hline Fertilizer & 1.0 & 0.5 & 2 & 15.3 & 6.5 & 0.001 \\
Year & 19.7 & 9.9 & 2 & 134.0 & 134.7 & $<0.001$ \\
Fertilizer $\times$ Year & 4.3 & 1.1 & 4 & 134.0 & 14.7 & $<0.001$ \\
\hline
\end{tabular}




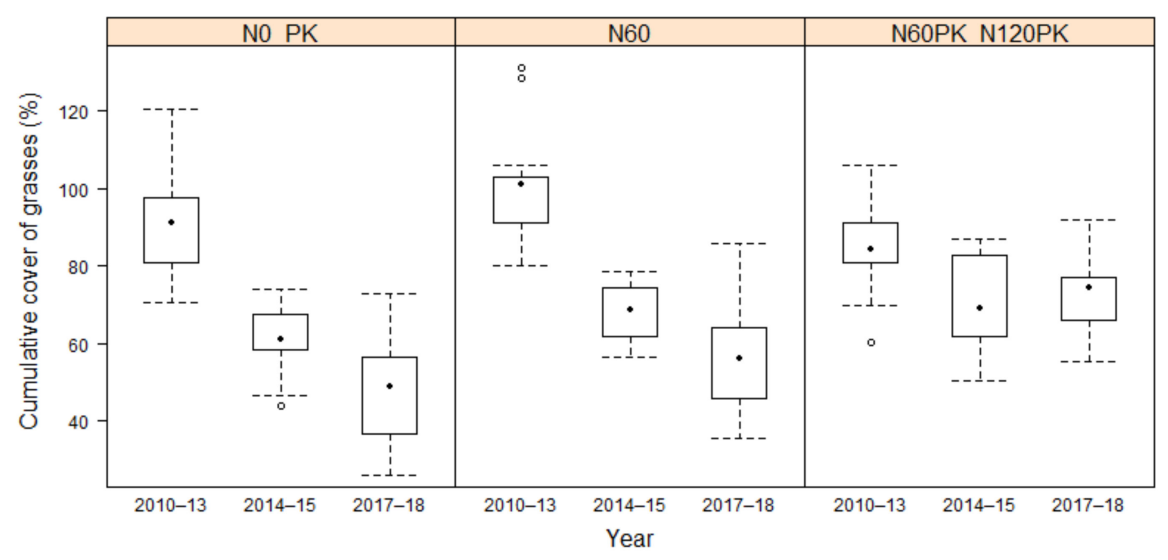

Figure 5. The minimal adequate model for the effect of fertilization treatment and time on the cumulative cover of grasses with different fertilization treatments between 2010 and 2018 (except 2016).

\subsubsection{Development of Legume Cover}

In 2010 before application of the treatments, the mean cover of legumes ranged between $15.0( \pm 5.1)$ and $22.3( \pm 8.4)$ and was formed by Lathyrus pratensis, Lotus corniculatus, Trifolium pratense, T. repens, T. dubium, Vicia sepium, V. cracca and V. tetrasperma. The treatment groups, i.e., N0 \& PK, N60 \& N120PK and N60PK developed significantly differently over time (Table 7), the former group with higher cover of legumes (Figure 6). From 2010 to 2011-2013 legume cover decreased considerably in all treatments and had almost disappeared in 2013. After the flood in 2013, legumes started to recover and increased continuously the following years. By the end of the study period in 2018, legume coverage in the N0 \& PK treatments was approaching baseline. Whereas in the nitrogen fertilization treatments, legume cover was still at a much lower level than their 2010 baseline.

Table 7. Effects of fertilizer and year on the cumulative cover of legumes according to the minimal adequate model. The model had three levels for the fertilizer and five levels for year (Figure 6).

\begin{tabular}{lcccccc}
\hline & Sum Sq & Mean Sq & NumDF & DenDF & F Value & $p$ \\
\hline Fertilizer & 4.3 & 2.1 & 2 & 17.0 & 6.2 & 0.009 \\
Year & 58.0 & 14.5 & 4 & 128.0 & 42.3 & $<0.001$ \\
Fertilizer $\times$ Year & 10.7 & 1.3 & 8 & 128.0 & 3.8 & $<0.001$ \\
\hline
\end{tabular}

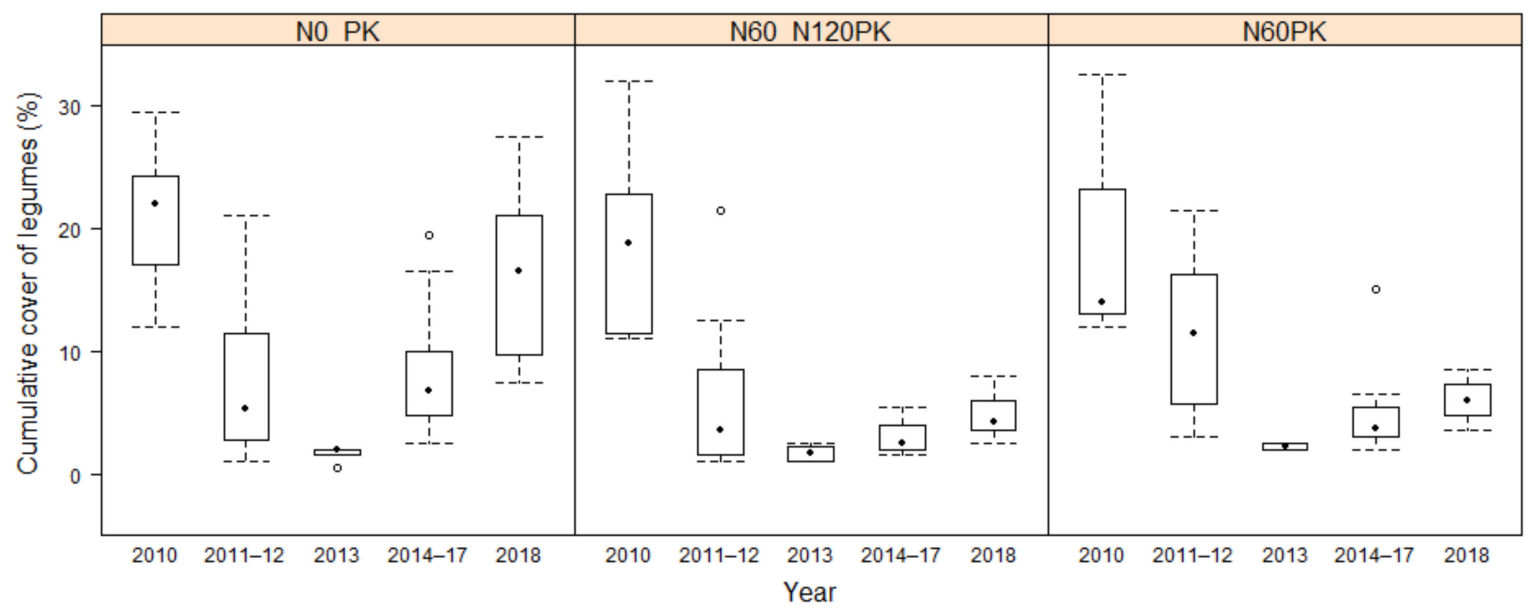

Figure 6. The minimal adequate model for the effect of fertilization treatment and time on the cumulative cover of legumes with different fertilization treatments between 2010 and 2018 (except 2016). 


\subsubsection{Development of Target Forbs Cover}

The cover of all target forbs and the cover of low-competitive forbs (Table A2) did not differ with respect to fertilization treatments, only for years (Tables A3 and A4, Figures A4 and A5). For the high-competitive target forbs, the treatment groups N0 \& PK \& N60PK and N60 \& N120PK developed differently over time (Table 8), the latter group with lower cover of high-competitive target forbs (Figure 7). The cover decreased significantly from 2010 to 2011-2013, before dropping significantly again in 2014, the year after the summer flooding, before significantly increasing the following years (Figure 7). In particular, the increase was consistent and large for the N0, PK and N60PK treatments that almost reached their 2010 baseline level. Cnidium dubium and Ranunculus acris were mainly responsible for this development (Figure A6).

Table 8. Effects of fertilizer and year on the cumulative cover of high-competitive target forbs according to the minimal adequate model. The model had two levels for the fertilizer and four levels for year (Figure 7).

\begin{tabular}{lcccccc}
\hline & Sum Sq & Mean Sq & NumDF & DenDF & F Value & $p$ \\
\hline Fertilizer & 1.1 & 1.1 & 1 & 19.6 & 5.4 & 0.031 \\
Year & 33.4 & 11.1 & 3 & 134.0 & 52.9 & $<0.001$ \\
Fertilizer $\times$ Year & 3.5 & 1.2 & 3 & 134.0 & 5.6 & 0.001 \\
\hline
\end{tabular}

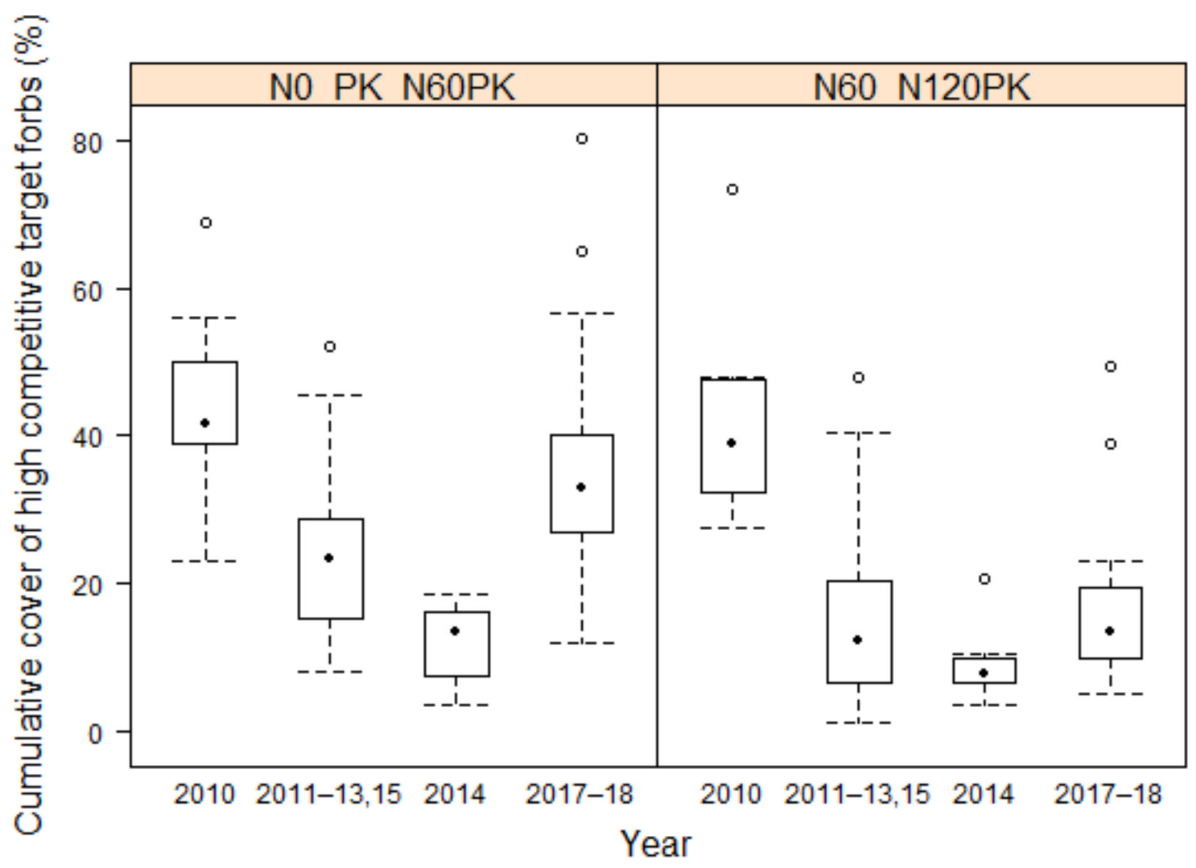

Figure 7. The minimal adequate model for the effect of fertilization treatment and time on the cumulative cover of high-competitive target forbs with different fertilization treatments between 2010 and 2018 (except 2016).

\section{Discussion}

\subsection{Effect of Fertilization on Forage Quality Parameters}

In the Dessau grassland experiment, the low forage quality of the alluvial grassland, which was prevalent at the beginning, could hardly be improved during the study period with any of the applied fertilizer treatments. For sheep feeding, the crude protein concentration and metabolizable energy concentration of both cuts were adequate for lowperformance phases (female sheep without lamb, rams not in breeding season) but did meet the needs of higher performance phases (lactating ewes, rams in the breeding season) only 
exceptionally. Our results are in line with other authors, who found only few effects on forage nutrient concentrations in alluvial grassland when nitrogen up to $200 \mathrm{~kg} \mathrm{ha}^{-1}$ year $^{-1}$ was applied [35] and in mountain grasslands when nitrogen $85 \mathrm{~kg}$, phosphorus oxide $80 \mathrm{~kg}$ and potassium oxide $240 \mathrm{~kg} \mathrm{ha}^{-1}$ year $^{-1}$ were applied [77]. The fertilization experiment by Dindová [38] showed a significant increase in crude protein concentration on a submontane Arrhenatherion grassland only when at least $200 \mathrm{~kg} \mathrm{ha}^{-1} \mathrm{year}^{-1}$ of nitrogen was supplied.

The 8-year study period may not have been long enough to trigger vegetation restructuring in the different fertilizer treatments. Schellberg et al. [78] stated that changes in botanical species composition in a mountain hay meadow fertilizer experiment improved forage quality by the increase of tall growing grasses only in a long-term process.

The significant changes between the years for all investigated parameters at both cuts indicate a typical year-to-year variability, which was also described by other authors [24,79], but seems to have been particularly affected by the summer flooding event. Exclusively after the summer flood, the tested nitrogen fertilizer treatments had such an increasing oneto two-year effect on crude protein concentration that higher requirements in sheep feeding could be met, while the metabolizable energy concentration responded in the opposite way. Blöschl et al. [80] predicted an increase of exceptional flooding events for the future and therefore, further research is needed to evaluate short- and long-term effects of flooding on forage quality parameters.

The decrease in forage quality for the second cut in the high-nitrogen-fertilized N120PK plots was visible at the end of the study period in the low crude protein concentration, low metabolizable energy and high crude fiber concentration. This could be related to the increase of Cirsium arvense, whose crude protein level decreases significantly in later stages of development in summer and fall [81]. Nitrogen fertilization promotes ruderal grassland forbs with low feeding values [12,46]. This is consistent with many twice-mowed, more heavily fertilized grasslands of the Dessau Elbe floodplain. The increase of ruderalization indicators such as Cirsium arvense, Elymus repens and Tanacetum vulgare L. is a phenomenon that has been increasingly observed there in recent years [82].

\subsection{Effect of Fertilization on Species Assembly}

\subsubsection{Grass and Legume Performance and Legume Cycle}

Interestingly, the effect of the nitrogen fertilization became apparent in the experiment only after the summer flood in 2013, but without the expected increase in grass cover as other authors stated $[33,36,39,53]$. An increase in grass cover can be achieved with even low to moderate nitrogen application of $35-50 \mathrm{~kg} \mathrm{ha}^{-1}$ year $^{-1}[33,83]$. However, the effect of nitrogen application can be influenced by water availability [84] or limitation by phosphorus $[85,86]$. Possibly, the low phosphorus content in the soil combined with the summer drying of the study site prevented an increase in grass cover. The tall grass Alopecurus pratensis was responsible for maintaining the grass cover, a result which is in agreement with those from the Jizera Mountains grassland experiment [87]. Elymus repens, which benefits from nitrogen fertilization [88], performed the same function in the N120PK treatment.

Compared to the Černíkovice grassland experiment [33], the legume cover was quite high at the beginning of the Dessau grassland experiment. It can be assumed that the vegetation was at the top of the curve of the legume cycle, as a strong decrease occurred in the following year, as also documented by Schwinning and Parsons $[43,89]$ in grazing systems. In the year after the summer flood, all plots suffered a great loss of legumes until their almost complete disappearance. Afterwards, their cover increased again only on the plots not fertilized with nitrogen and approached the initial state after eight years. This period corresponds to the legume cycle duration in permanent grasslands [44]. The persistently low cover of legumes in plots with nitrogen application is consistent with the results from other long-term experiments, not only on alluvial grasslands $[33,53,83,87,90]$. Our study illustrates for alluvial grasslands that the legume cycle could be maintained only for the non-nitrogen-fertilized plots, as already described for montane grasslands [44]. 
The fact that no difference in legume cover was found between the unfertilized control and PK fertilization treatments contradicts the findings for montane grasslands, where legumes benefited from PK fertilization compared to unfertilized controls [91].

These results are however in line with the Černíkovice alluvial grassland experiment, where legumes achieved the highest cover in the control and PK treatments [33].

Legumes can have a significant influence on the forage quality and elasticity of forage utilization by maintaining overall sward digestibility over a longer period [92], increasing protein in fodder [93] or increasing the mineral content [94]. In addition, they can play an important role for securing the feed supply for livestock with regard to future climatic conditions. Legumes are well adapted to higher temperatures and can also use water reserves in deeper soil layers through their deep root system [42].

\subsubsection{Target Species Number and Target Forbs Cover}

Contrary to the assumption that alluvial grassland target species number decreases under nitrogen fertilization according to species richness [33,95], there was no decline during the 8-year study period. This is in accordance with the Steinach grassland experiment, the results of which concluded that species composition in productive alluvial grasslands is substantially less affected by fertilizer application than in low-productivity grasslands [36]. Flooding events act as a major influencing factor by overruling the fertilization effects on species richness [96]. Although the study area was no longer flooded annually in the spring during the study period, it seems that the exceptional summer flood of 2013 was sufficient to produce this effect. In addition to flooding events, the low soil phosphorus level in the studied alluvial grassland could also be responsible for the persistence of target species. Several authors [97-99] found that low soil phosphorus availability seems to be a key factor in maintaining high species richness. Moreover, in the Dessau grassland experiment, no soil-acidifying nitrogen fertilizer was applied which, according to Hejcman et al. [36], can also have a positive effect on maintaining the target species number.

The assumption that nitrogen fertilization leads to a decrease in cover of low-competitive target forbs cannot be confirmed. This can be explained by the fact that the grass cover did not increase under nitrogen fertilization as observed in other grassland experiments $[33,36,39,53]$. Furthermore, the expected increase in light competition and niche dimension reduction $[52,100]$ has not occurred in our study. In addition, low-competitive species present on the study site, such as the target forbs Cardamine pratensis L., Prunella vulgaris L., Ranunculus auricomus L. and Veronica chamaedrys L., responded neutrally to fertilization as also described by Busch et al. [55]. In contrast, after declining in the first four years of the experiment, the high-competitive target forbs did not reach the 2010 level after the summer flood on the nitrogen-fertilized plots, which can be attributed to the fact that even high-competitive species can be negatively affected by nitrogen fertilization [55]. On the plots without nitrogen fertilization, however, some species (e.g., Selinum dubium and Ranunculus acris) clearly benefited from the summer flood by considerably increasing their cover. Interestingly, the negative effect of moderate nitrogen fertilization (N60) was compensated for by additional P and $\mathrm{K}$ fertilization (N60PK). This is confirmed by Kidd et al. [83], whose study showed that nitrogen fertilization alone has a stronger negative effect than in combination with phosphorus and potassium.

\section{Conclusions}

Regarding forage quality, no significant improvement could be achieved for sheep feeding. Both cuts provided sufficient crude protein concentrations for low-performance phases in all treatments. The concentration was significantly improved by higher nitrogen fertilization, but higher feeding requirements of lamb-rearing ewes or rams in breeding season were only met in individual years. Especially in the second cut, the metabolizable energy concentration decreased during the study period independent of fertilization treatment and in most years not even the requirements of the low-performance phases were met. Concerning species assembly, we found that moderate application of N60PK 
does not generate irreversible changes in target forbs cover, but hampers the legume cycle of permanent alluvial grassland. N60 without PK fertilization additionally shows clear negative effects on high-competitive target forbs cover and applying N120PK, the originally good conservation status of the alluvial grassland deteriorates due to the strongest increase of the tall grass Alopecurus pratensis and the ruderal species Cirsium arvense and Elymus repens. For N60 and N120PK, irreversible damage in species assembly cannot be ruled out in the case of further application beyond the study period and should therefore not be applied on species-rich alluvial grasslands that have good conservation status.

Supplementary Materials: The following are available online at https: / www.mdpi.com/article/ 10.3390/agriculture11040339/s1, Table S1: Raw data of the forage quality parameters (crude fiber, crude protein, metabolizable energy).

Author Contributions: Conceptualization, S.D., U.G.J. and S.T.; data curation, S.D.; formal analysis, K.R. and S.D.; funding acquisition, S.D. and S.T.; investigation, S.D., U.G.J. and M.H.M.; methodology, S.D. and U.G.J.; project administration, S.D.; writing-original draft, S.D., K.R., A.K.; writing-review and editing, S.D., K.R., A.K., S.T. and M.H.M. All authors have read and agreed to the published version of the manuscript.

Funding: This study was funded by the state administrative authority of Saxony-Anhalt (ELER funding, grant no. 407.1.2-60128/323010000010, 407.1.2-60128/323011000033, 407.1.2-60128/323012000058, 407.1.2-60128/630116000012).

Data Availability Statement: Data of forage quality parameters (crude protein, crude fiber and metabolizable energy) are provided as a source data file on https:/ / opendata.uni-halle.de, accessed on 28 March 2021. All other data presented in this study are available on request from the corresponding author.

Acknowledgments: The authors would like to thank Friedrich and Danilo Helm from the Landwirtschaftsgesellschaft Dessau Mildensee for providing the meadow for the study and their support in trial management. We are grateful to Hendrik Pannach from the Biosphere Reserve Mittelelbe for assistance with study area search and information on grassland use of the Elbe floodplain, to several colleagues, in particular Nele Adert, Heiner Hensen, Gerd Jünger, Henriette John, Anja Friedrich and Kerstin Reißmann, for their help with the field work and to Keith Edwards for language corrections.

Conflicts of Interest: The authors declare no conflict of interest.

\section{Appendix A}
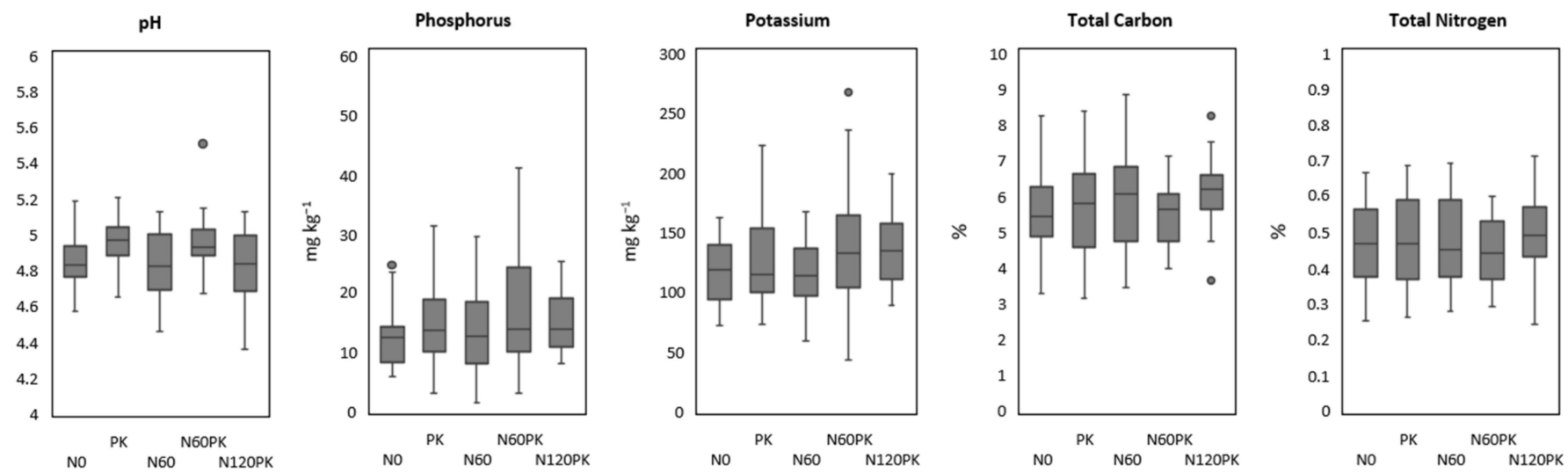

Figure A1. Soil chemical characteristics of fertilization treatments during the study period (soil sampling in 2010-2015, 2017). All variables did not significantly differ between treatments according to the generalized linear mixed model (GLMM). 
Table A1. Means values and standard deviation (in brackets) of crude fiber (g kg DM $\left.{ }^{-1}\right)$, crude protein $\left(\mathrm{g} \mathrm{kg} \mathrm{DM}^{-1}\right)$ and metabolizable energy (MJ kg DM$\left.{ }^{-1}\right)$.

\begin{tabular}{|c|c|c|c|c|c|c|c|c|c|c|c|c|}
\hline \multirow{2}{*}{$\begin{array}{l}\text { Year } \\
\text { Cut }\end{array}$} & \multicolumn{2}{|c|}{2010} & \multicolumn{2}{|c|}{2011} & \multicolumn{2}{|c|}{2012} & \multicolumn{2}{|c|}{2014} & \multicolumn{2}{|c|}{2015} & \multicolumn{2}{|c|}{2017} \\
\hline & First & Second & First & Second & First & Second & First & Second & First & Second & First & Second \\
\hline \multicolumn{13}{|c|}{ Crude fiber (g kg DM ${ }^{-1}$ ) } \\
\hline No & $\begin{array}{c}268 \\
(18.8)\end{array}$ & $\begin{array}{c}242 \\
(17.8)\end{array}$ & $\begin{array}{c}257 \\
(9.2)\end{array}$ & $\begin{array}{c}291 \\
(7.8)\end{array}$ & $\begin{array}{c}295 \\
(8.1)\end{array}$ & $\begin{array}{c}278 \\
(19.3)\end{array}$ & $\begin{array}{c}292 \\
(4.5)\end{array}$ & $\begin{array}{c}281 \\
(15.7)\end{array}$ & $\begin{array}{c}267 \\
(13.0)\end{array}$ & $\begin{array}{c}267 \\
(17.4)\end{array}$ & $\begin{array}{c}280 \\
(20.9)\end{array}$ & $\begin{array}{c}266 \\
(36.5)\end{array}$ \\
\hline PK & $\begin{array}{c}285 \\
(4.5)\end{array}$ & $\begin{array}{c}241 \\
(5.3)\end{array}$ & $\begin{array}{c}259 \\
(10.1)\end{array}$ & $\begin{array}{l}290 \\
(9.8)\end{array}$ & $\begin{array}{c}289 \\
(13.1)\end{array}$ & $\begin{array}{c}292 \\
(4.1)\end{array}$ & $\begin{array}{c}284 \\
(23.4)\end{array}$ & $\begin{array}{c}297 \\
(35.2)\end{array}$ & $\begin{array}{c}262 \\
(14.7)\end{array}$ & $\begin{array}{c}254 \\
(32.6)\end{array}$ & $\begin{array}{l}278 \\
(9.2)\end{array}$ & $\begin{array}{c}275 \\
(30.5)\end{array}$ \\
\hline N60 & $\begin{array}{c}269 \\
(12.1)\end{array}$ & $\begin{array}{c}227 \\
(17.9)\end{array}$ & $\begin{array}{c}257 \\
(13.9)\end{array}$ & $\begin{array}{c}287 \\
(12.6)\end{array}$ & $\begin{array}{l}288 \\
(11)\end{array}$ & $\begin{array}{l}288 \\
(9.2)\end{array}$ & $\begin{array}{c}293 \\
(14.8)\end{array}$ & $\begin{array}{c}279 \\
(12.6)\end{array}$ & $\begin{array}{c}268 \\
(15.1)\end{array}$ & $\begin{array}{c}268 \\
(18.3)\end{array}$ & $\begin{array}{c}284 \\
(17.8)\end{array}$ & $\begin{array}{c}270 \\
(27.9)\end{array}$ \\
\hline N60PK & $\begin{array}{c}282 \\
(15.4)\end{array}$ & $\begin{array}{c}237 \\
(14.1)\end{array}$ & $\begin{array}{c}258 \\
(18.3)\end{array}$ & $\begin{array}{c}286 \\
(9.1)\end{array}$ & $\begin{array}{c}306 \\
(24.1)\end{array}$ & $\begin{array}{c}284 \\
(12.0)\end{array}$ & $\begin{array}{c}300 \\
(4.5)\end{array}$ & $\begin{array}{c}286 \\
(19.8)\end{array}$ & $\begin{array}{c}271 \\
(10.0)\end{array}$ & $\begin{array}{c}258 \\
(13.8)\end{array}$ & $\begin{array}{c}305 \\
(4.7)\end{array}$ & $\begin{array}{c}293 \\
(20.2)\end{array}$ \\
\hline N120PK & $\begin{array}{c}289 \\
(9.7)\end{array}$ & $\begin{array}{c}254 \\
(14.7)\end{array}$ & $\begin{array}{c}268 \\
(9.6)\end{array}$ & $\begin{array}{l}284 \\
(5.9)\end{array}$ & $\begin{array}{c}297 \\
(5.4)\end{array}$ & $\begin{array}{c}286 \\
(10.9)\end{array}$ & $\begin{array}{c}293 \\
(12.9)\end{array}$ & $\begin{array}{c}284 \\
(11.6)\end{array}$ & $\begin{array}{c}268 \\
(15.7)\end{array}$ & $\begin{array}{c}250 \\
(17.6)\end{array}$ & $\begin{array}{c}308 \\
(19.9)\end{array}$ & $\begin{array}{c}320 \\
(23.6)\end{array}$ \\
\hline \multicolumn{13}{|c|}{ Crude protein (g kg DM ${ }^{-1}$ ) } \\
\hline No & $\begin{array}{c}101 \\
(6.1)\end{array}$ & $\begin{array}{c}124 \\
(4.5)\end{array}$ & $\begin{array}{c}90 \\
(15.1) \\
\end{array}$ & $\begin{array}{c}121 \\
(16.5) \\
\end{array}$ & $\begin{array}{c}96 \\
(5.9) \\
\end{array}$ & $\begin{array}{c}102 \\
(10.9) \\
\end{array}$ & $\begin{array}{c}110 \\
(8.5)\end{array}$ & $\begin{array}{c}113 \\
(6.3) \\
\end{array}$ & $\begin{array}{c}100 \\
(5.1)\end{array}$ & $\begin{array}{c}116 \\
(3.9)\end{array}$ & $\begin{array}{c}99 \\
(4.2) \\
\end{array}$ & $\begin{array}{c}107 \\
(11.1) \\
\end{array}$ \\
\hline PK & $\begin{array}{c}102 \\
(6.7) \\
\end{array}$ & $\begin{array}{c}116 \\
(7.6) \\
\end{array}$ & $\begin{array}{c}94 \\
(9.3) \\
\end{array}$ & $\begin{array}{c}120 \\
(13.7) \\
\end{array}$ & $\begin{array}{c}92 \\
(1.2) \\
\end{array}$ & $\begin{array}{c}94 \\
(8.9) \\
\end{array}$ & $\begin{array}{c}97 \\
(5.1) \\
\end{array}$ & $\begin{array}{c}107 \\
(12.6) \\
\end{array}$ & $\begin{array}{c}99 \\
(8.9) \\
\end{array}$ & $\begin{array}{c}110 \\
(17.7) \\
\end{array}$ & $\begin{array}{c}96 \\
(4.9) \\
\end{array}$ & $\begin{array}{c}104 \\
(11.6) \\
\end{array}$ \\
\hline N60 & $\begin{array}{c}99 \\
(7.5) \\
\end{array}$ & $\begin{array}{c}115 \\
(3.1) \\
\end{array}$ & $\begin{array}{c}96 \\
(4.7) \\
\end{array}$ & $\begin{array}{c}124 \\
(16.4) \\
\end{array}$ & $\begin{array}{c}111 \\
(12.7) \\
\end{array}$ & $\begin{array}{c}105 \\
(8.1) \\
\end{array}$ & $\begin{array}{c}121 \\
(5.3) \\
\end{array}$ & $\begin{array}{c}132 \\
(11.5) \\
\end{array}$ & $\begin{array}{c}118 \\
(9.1) \\
\end{array}$ & $\begin{array}{c}124 \\
(7.5) \\
\end{array}$ & $\begin{array}{c}117 \\
(10.5) \\
\end{array}$ & $\begin{array}{c}115 \\
(11.5) \\
\end{array}$ \\
\hline N60PK & $\begin{array}{c}101 \\
(3.5) \\
\end{array}$ & $\begin{array}{c}118 \\
(9.2) \\
\end{array}$ & $\begin{array}{c}94 \\
(6.2) \\
\end{array}$ & $\begin{array}{c}121 \\
(7.6) \\
\end{array}$ & $\begin{array}{c}113 \\
(14.9) \\
\end{array}$ & $\begin{array}{c}110 \\
(13.8) \\
\end{array}$ & $\begin{array}{c}126 \\
(22.1) \\
\end{array}$ & $\begin{array}{c}142 \\
(17.2) \\
\end{array}$ & $\begin{array}{c}114 \\
(8.5) \\
\end{array}$ & $\begin{array}{c}115 \\
(22.4) \\
\end{array}$ & $\begin{array}{c}101 \\
(6.5) \\
\end{array}$ & $\begin{array}{c}105 \\
(6.4) \\
\end{array}$ \\
\hline N120PK & $\begin{array}{c}108 \\
(6.0)\end{array}$ & $\begin{array}{c}120 \\
(4.6)\end{array}$ & $\begin{array}{c}104 \\
(8.9)\end{array}$ & $\begin{array}{c}116 \\
(9.6) \\
\end{array}$ & $\begin{array}{c}104 \\
(11.3) \\
\end{array}$ & $\begin{array}{c}116 \\
(12.6) \\
\end{array}$ & $\begin{array}{c}130 \\
(8.9) \\
\end{array}$ & $\begin{array}{c}150 \\
(13.6) \\
\end{array}$ & $\begin{array}{c}131 \\
(11.7)\end{array}$ & $\begin{array}{c}137 \\
(19.6)\end{array}$ & $\begin{array}{c}118 \\
(8.3)\end{array}$ & $\begin{array}{c}98 \\
(10.9)\end{array}$ \\
\hline \multicolumn{13}{|c|}{ Metabolizable energy (MJ kg DM ${ }^{-1}$ ) } \\
\hline No & $\begin{array}{c}9.2 \\
(0.3)\end{array}$ & $\begin{array}{c}9.6 \\
(0.8)\end{array}$ & $\begin{array}{c}9.5 \\
(0.1)\end{array}$ & $\begin{array}{c}8.7 \\
(0.3)\end{array}$ & $\begin{array}{c}8.7 \\
(0.2)\end{array}$ & $\begin{array}{c}9.3 \\
(0.3)\end{array}$ & $\begin{array}{c}8.5 \\
(0.1)\end{array}$ & $\begin{array}{c}8.1 \\
(0.5)\end{array}$ & $\begin{array}{c}8.8 \\
(0.4)\end{array}$ & $\begin{array}{l}9.2 \\
(0.4)\end{array}$ & $\begin{array}{c}9.0 \\
(0.2)\end{array}$ & $\begin{array}{c}9.0 \\
(0.6)\end{array}$ \\
\hline PK & $\begin{array}{c}9.0 \\
(0.1)\end{array}$ & $\begin{array}{l}10.1 \\
(0.3)\end{array}$ & $\begin{array}{c}9.5 \\
(0.2)\end{array}$ & $\begin{array}{c}8.8 \\
(0.2)\end{array}$ & $\begin{array}{c}8.6 \\
(0.3)\end{array}$ & $\begin{array}{l}9.0 \\
(0.2)\end{array}$ & $\begin{array}{c}8.5 \\
(0.5)\end{array}$ & $\begin{array}{c}7.9 \\
(0.3)\end{array}$ & $\begin{array}{c}9.1 \\
(0.4)\end{array}$ & $\begin{array}{c}9.1 \\
(0.8)\end{array}$ & $\begin{array}{c}8.8 \\
(0.3)\end{array}$ & $\begin{array}{c}8.9 \\
(0.4) \\
\end{array}$ \\
\hline N60 & $\begin{array}{c}9.3 \\
(0.2)\end{array}$ & $\begin{array}{c}9.9 \\
(0.5)\end{array}$ & $\begin{array}{l}9.5 \\
(0.3)\end{array}$ & $\begin{array}{c}8.9 \\
(0.2)\end{array}$ & $\begin{array}{l}9.0 \\
(0.2)\end{array}$ & $\begin{array}{c}9.3 \\
(0.3)\end{array}$ & $\begin{array}{c}8.7 \\
(0.4)\end{array}$ & $\begin{array}{c}8.1 \\
(0.4)\end{array}$ & $\begin{array}{c}8.9 \\
(0.4) \\
\end{array}$ & $\begin{array}{c}8.9 \\
(0.5)\end{array}$ & $\begin{array}{c}8.9 \\
(0.2)\end{array}$ & $\begin{array}{c}8.6 \\
(0.5) \\
\end{array}$ \\
\hline N60PK & $\begin{array}{c}8.9 \\
(0.2) \\
\end{array}$ & $\begin{array}{l}10.0 \\
(0.2)\end{array}$ & $\begin{array}{c}9.4 \\
(0.4) \\
\end{array}$ & $\begin{array}{c}8.9 \\
(0.2) \\
\end{array}$ & $\begin{array}{c}8.5 \\
(0.4) \\
\end{array}$ & $\begin{array}{c}9.3 \\
(0.3) \\
\end{array}$ & $\begin{array}{c}8.4 \\
(0.3) \\
\end{array}$ & $\begin{array}{c}7.8 \\
(0.2) \\
\end{array}$ & $\begin{array}{c}8.5 \\
(0.6) \\
\end{array}$ & $\begin{array}{c}8.9 \\
(0.6)\end{array}$ & $\begin{array}{c}8.4 \\
(0.2) \\
\end{array}$ & $\begin{array}{c}8.4 \\
(0.4) \\
\end{array}$ \\
\hline N120PK & $\begin{array}{c}8.9 \\
(0.2)\end{array}$ & $\begin{array}{c}9.4 \\
(0.4)\end{array}$ & $\begin{array}{c}9.3 \\
(0.2)\end{array}$ & $\begin{array}{c}8.7 \\
(0.3)\end{array}$ & $\begin{array}{c}8.9 \\
(0.2)\end{array}$ & $\begin{array}{c}9.1 \\
(0.3)\end{array}$ & $\begin{array}{c}8.6 \\
(0.1)\end{array}$ & $\begin{array}{c}7.6 \\
(0.3)\end{array}$ & $\begin{array}{c}9.0 \\
(0.4)\end{array}$ & $\begin{array}{c}9.4 \\
(0.4)\end{array}$ & $\begin{array}{c}8.4 \\
(0.3)\end{array}$ & $\begin{array}{c}7.7 \\
(0.6)\end{array}$ \\
\hline
\end{tabular}

(a)

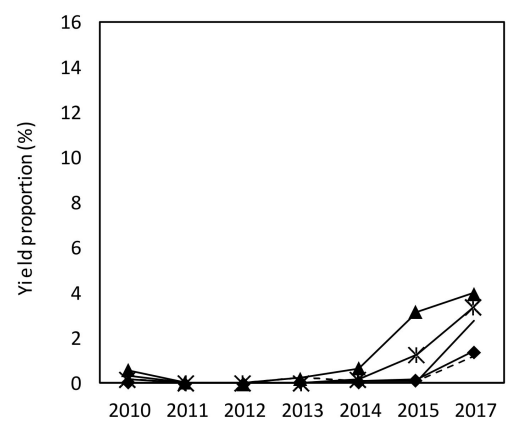

(b)

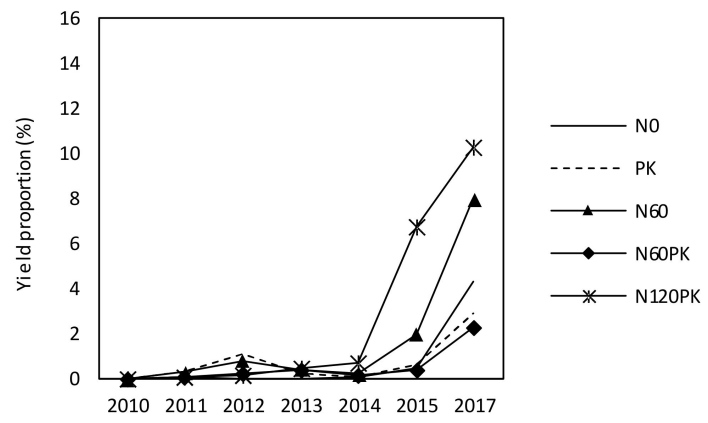

Figure A2. Percentage contribution of Cirsium arvense to the aboveground plant biomass in the first (a) and second (b) cuts with different fertilization treatments between 2010 and 2017 (except 2016). Two years after the extreme summer flood in 2013, the treatments N60 and N120PK most strongly increased. 

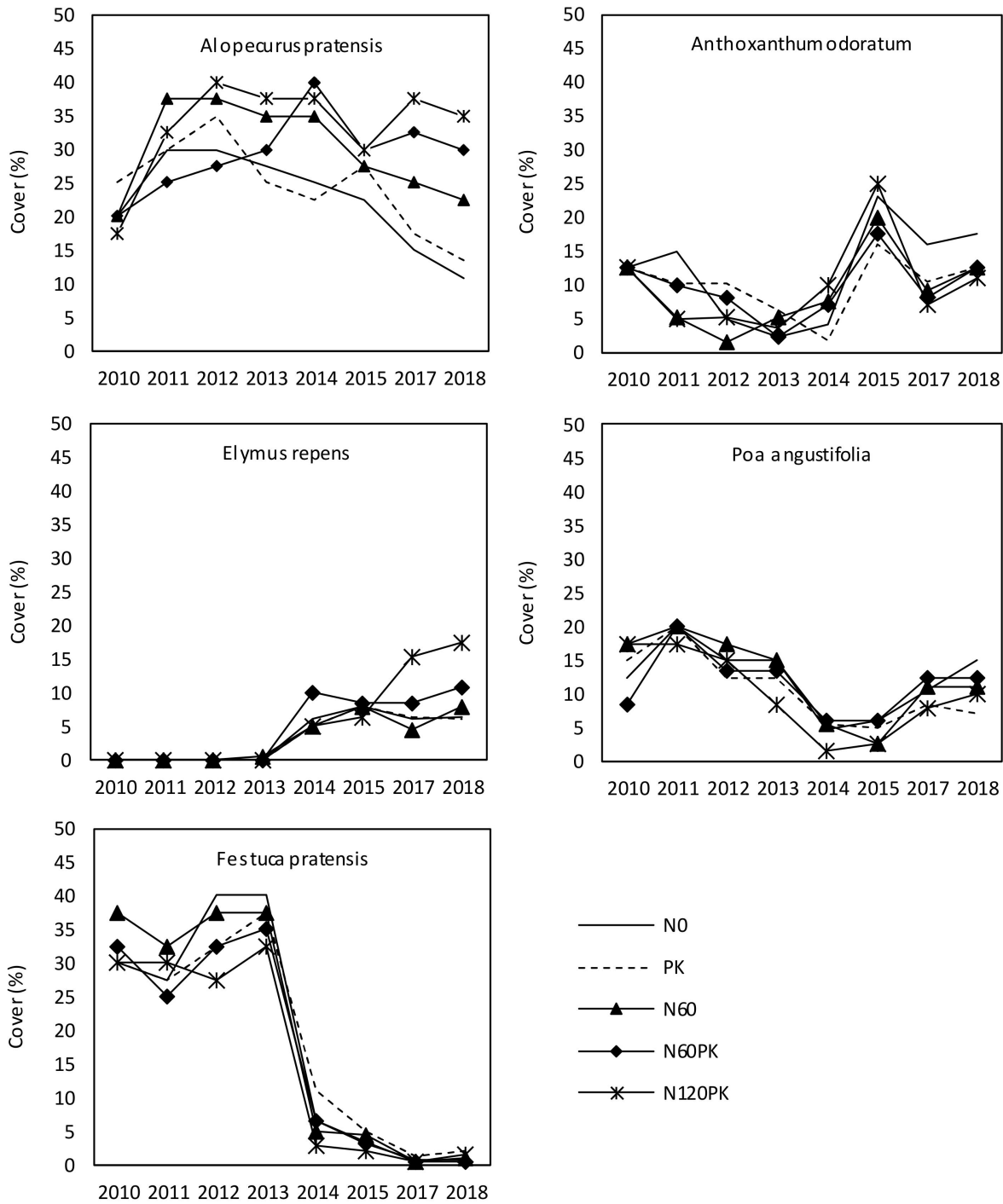

Figure A3. Development of percentage cover of the five most important grasses with different fertilization treatments between 2010 and 2018 (except 2016).

Table A2. Target species (characteristic species of habitat type 6440 (LAU 2010)), characteristic species and low-growing forbs of the Sanguisorbo officinalis-Silaetum silai (Schubert [58]). High-competitive target forbs (hc) = ecological strategy types C and CS (after Grime et al. [71]), all other species belong to the group of low-competitive target forbs.

\begin{tabular}{lll}
\hline Target forbs (including legumes) & Prunella vulgaris & Viola stagnina \\
\hline Achillea millefolium $(\mathrm{hc})$ & Ranunculus acris $(\mathrm{hc})$ & Target grasses \\
\hline Allium angulosum & Ranunculus auricomus & Agrostis capillaris \\
\hline Cardamine pratensis & Ranunculus polyanthemos $(\mathrm{hc})$ & Alopecurus pratensis \\
\hline Centaurea jacea $(\mathrm{hc})$ & Rumex acetosa $(\mathrm{hc})$ & Anthoxanthum odoratum \\
\hline Daucus carota & Sanguisorba officinalis $(\mathrm{hc})$ & Carex acuta \\
\hline Euphorbia esula & Selinum dubium $(\mathrm{hc})$ & Carex disticha \\
\hline Galium album $(\mathrm{hc})$ & Senecio aquaticus & Carex nigra \\
\hline Galium boreale & Silaum silaus $(\mathrm{hc})$ & Carex praecox \\
\hline Inula salicina & Thalictrum flavum $(\mathrm{hc})$ & Deschampsia cespitosa \\
\hline
\end{tabular}


Table A2. Cont.

\begin{tabular}{lll}
\hline Lathyrus pratensis $(\mathrm{hc})$ & Trifolium pratense $(\mathrm{hc})$ & Luzula campestris \\
\hline Leucanthemum ircutianum $(\mathrm{hc})$ & Veronica chamaedrys & Poa angustifolia \\
\hline Lotus corniculatus & Veronica maritima $(\mathrm{hc})$ & Poa trivialis \\
\hline Lychnis flos-cuculi & Vicia sepium $(\mathrm{hc})$ & \\
\hline
\end{tabular}

Table A3. Effects of year on the cumulative cover of target forbs according to the minimal adequate model. The model had three levels for year (Figure A4).

\begin{tabular}{ccccccc}
\hline & Sum Sq & Mean Sq & NumDF & DenDF & F Value & $p$ \\
\hline Year & 25.8 & 12.9 & 2 & 138 & 62.5 & $<0.001$ \\
\hline
\end{tabular}

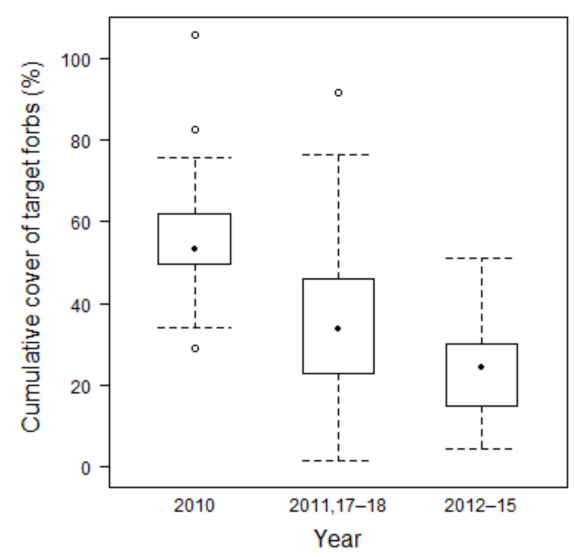

Figure A4. The minimal adequate model for the effect of time on the cumulative cover of target forbs with different fertilization treatments between 2010 and 2018 (except 2016).

Table A4. Effects of year on the cumulative cover of low-competitive target forbs according to the minimal adequate model. The model had four levels for year (Figure A5).

\begin{tabular}{ccccccc}
\hline & Sum Sq & Mean Sq & NumDF & DenDF & F Value & $p$ \\
\hline Year & 26.1 & 8.7 & 3 & 137 & 29.2 & $<0.001$ \\
\hline
\end{tabular}

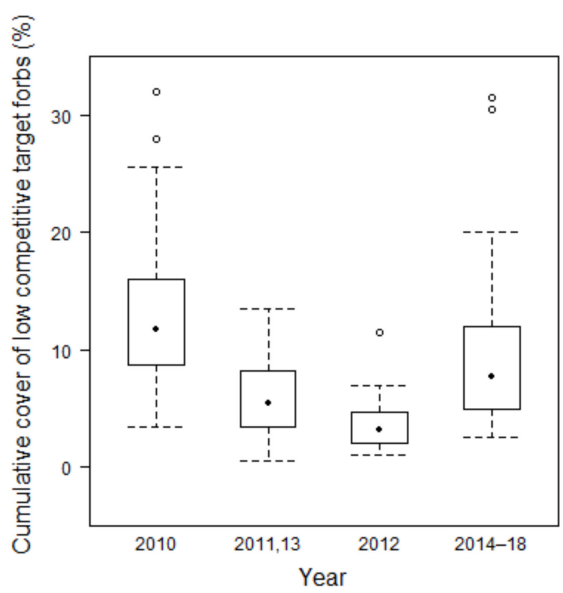

Figure A5. The minimal adequate model for the effect of time on the cumulative cover of lowcompetitive target forbs with different fertilization treatments between 2010 and 2018 (except 2016). 

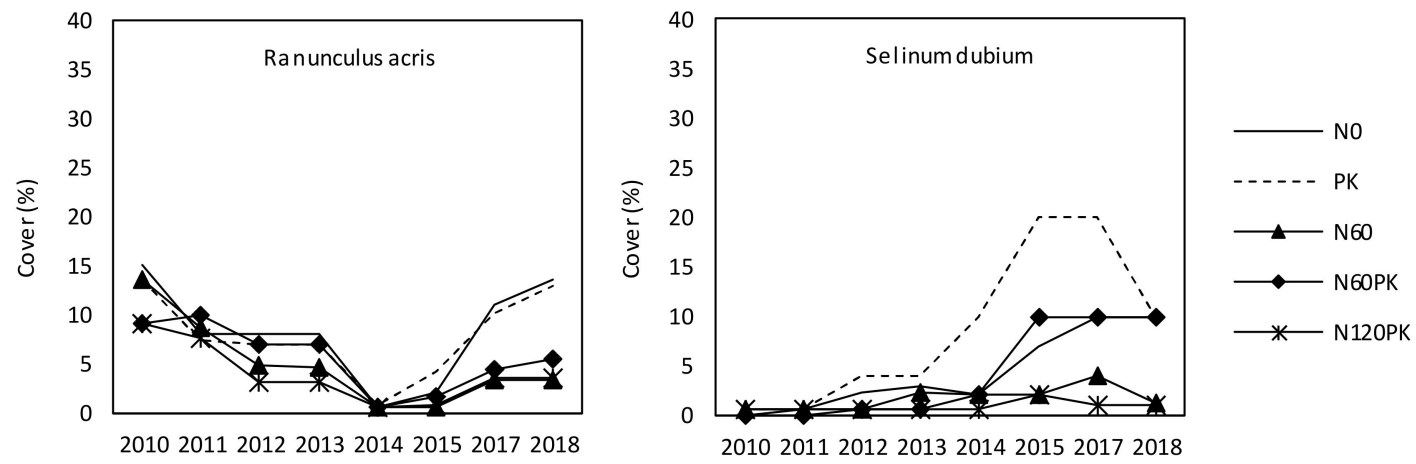

Figure A6. Development of percentage cover of the high-competitive target forbs Ranunculus acris and Selinum dubium with different fertilization treatments between 2010 and 2018 (except 2016).

\section{References}

1. Isselstein, J.; Jeangros, B.; Pavlů, V. Agronomic aspects of biodiversity targeted management of temperate grasslands in Europe-A review. Agron. Res. 2005, 3, 139-151.

2. Peyraud, J.-L.; Peeters, A. The role of grassland based production system in the protein security. In Grassland Science in Europe-The Multiple Roles of Grassland in the European Bioeconomy, Proceedings of the 26th General Meeting of the European Grassland Federation (EGF), Trondheim, Norway, 4-8 September 2016; Höglind, M., Bakken, A.K., Hovstad, K.A., Kallioniemi, E., Riley, H., Steinshamn, H., Østrem, L., Eds.; Norwegian Institue of Bioeconomy Research: Wageningen, The Netherlands, 2016; Volume 21, pp. $29-43$.

3. Bengtsson, J.; Bullock, J.M.; Egoh, B.; Everson, C.; Everson, T.; O'Connor, T.; O’Farrell, P.J.; Smith, H.G.; Lindborg, R. Grasslandsmore important for ecosystem services than you might think. Ecosphere 2019, 10, e02582. [CrossRef]

4. Garland, G.; Banerjee, S.; Edlinger, A.; Oliveira, E.; Herzog, C.; Wittwer, R.; Philippot, L.; Maestre, F.; Van der Heijden, M. A closer look at the functions behind ecosystem multifunctionality: A review. J. Ecol. 2020, 109, 1-14. [CrossRef]

5. Manning, P.; van der Plas, F.; Soliveres, S.; Allan, E.; Maestre, F.T.; Mace, G.; Whittingham, M.J.; Fischer, M. Redefining ecosystem multifunctionality. Nat. Ecol. Evol. 2018, 2, 427-436. [CrossRef]

6. Zhao, Y.; Liu, Z.; Wu, J. Grassland ecosystem services: A systematic review of research advances and future directions. Landsc. Ecol. 2020, 35, 793-814. [CrossRef]

7. Boval, M.; Dixon, R.M. The importance of grasslands for animal production and other functions: A review on management and methodological progress in the tropics. Animal 2012, 6, 748-762. [CrossRef]

8. Berauer, B.J.; Wilfahrt, P.A.; Reu, B.; Schuchardt, M.A.; Garcia-Franco, N.; Zistl-Schlingmann, M.; Dannenmann, M.; Kiese, R.; Kühnel, A.; Jentsch, A. Predicting forage quality of species-rich pasture grasslands using vis-NIRS to reveal effects of management intensity and climate change. Agric. Ecosyst. Environ. 2020, 296, 106929. [CrossRef]

9. Orford, K.A.; Murray, P.J.; Vaughan, I.P.; Memmott, J. Modest enhancements to conventional grassland diversity improve the provision of pollination services. J. Appl. Ecol. 2016, 53, 906-915. [CrossRef] [PubMed]

10. Dengler, J.; Janišová, M.; Török, P.; Wellstein, C. Biodiversity of Palaearctic grasslands: A synthesis. Agric. Ecosyst. Environ. 2014, 182, 1-14. [CrossRef]

11. Van Dijk, G. The status of semi-natural grasslands in Europe. In The Conservation of Lowland Dry Grassland Birds in Europe, Reading, 20-22 March 1991; Goriup, P.D., Batten, L.A., Norton, J.A., Eds.; JNCC Publication: Newbury, UK, 1991; pp. 15-36.

12. Wesche, K.; Krause, B.; Culmsee, H.; Leuschner, C. Fifty years of change in Central European grassland vegetation: Large losses in species richness and animal-pollinated plants. Biol. Conserv. 2012, 150, 76-85. [CrossRef]

13. Diekmann, M.; Andres, C.; Becker, T.; Bennie, J.; Blueml, V.; Bullock, J.; Culmsee, H.; Fanigliulo, M.; Hahn, A.; Heinken, T.; et al. Patterns of long-term vegetation change vary between different types of semi-natural grasslands in Western and Central Europe. J. Veg. Sci. 2019, 30, 187-202. [CrossRef]

14. Council of the European Commission. Council directive 92/43/EEC of 21 May 1992 on the conservation of natural habitats and of wild fauna and flora. Off. J. Eur. Union L 1992, 206, 7-49.

15. European Commission. Interpretation Manual of European Union Habitats-EUR 27; European Commission, DG Environment, Nature and Conservation: Brussels, Belgium, 2007.

16. Šeffer, J.; Janák, M.; Šefferová Stanová, V. Management Models for Habitats in Natura 2000 Sites. 6440 Alluvial Meadows of River Valleys of the Cnidion Dubii; European Commission Technical Report 2008: 17/24. European Commission, 2008; p. 20, ISBN 978-92-79-08337-2. Available online: https:/ / ec.europa.eu/environment/nature/natura2000/management/habitats/pdf/6440_Alluvial_meadows.pdf (accessed on 21 January 2021).

17. Hölzel, N.; Donath, T.W.; Bissels, S.; Otte, A. Auengrünlandrenaturierung am hessischen Oberrhein -Defizite und Erfolge nach 15 Jahren Laufzeit. Schriftenr. Veg. 2002, 36, 131-137.

18. Bischoff, A.; Warthemann, G.; Klotz, S. Succession of floodplain grasslands following reduction in land use intensity: The importance of environmental conditions, management and dispersal. J. Appl. Ecol. 2009, 46, 241-249. [CrossRef] 
19. Bischoff, A.; Hoboy, S.; Winter, N.; Warthemann, G. Hay and seed transfer to re-establish rare grasslandspecies and communities: How important are date andsoil preparation? Biol. Conserv. 2018, 221, 182-189. [CrossRef]

20. Bundesamt für Naturschutz (BfN). Ergebnisse Nationaler FFH-Bericht 2019, Erhaltungszustände und Gesamttrends der Lebensraumtypen (LRT) in der Atlantischen Biogeographischen Region. 2019. Available online: https://www.bfn.de/fileadmin/BfN/ natura2000/Dokumente/nat_bericht_LRT_EHZ_Gesamttrend_ATL_20190830.pdf (accessed on 21 January 2021).

21. Bundesamt für Naturschutz (BfN). Ergebnisse Nationaler FFH-Bericht 2019, Erhaltungszustände und Gesamttrends der Lebensraumtypen (LRT) in der Kontinentalen Biogeographischen Region. 2019. Available online: https://www.bfn.de/fileadmin/ BfN/natura2000/Dokumente/nat_bericht_LRT_EHZ_Gesamttrend_KON_20190830.pdf (accessed on 21 January 2021).

22. Franke, C. Grünland an der unteren Mittelelbe. Vegetationsökologie und landwirtschaftliche Nutzbarkeit. Diss. Bot. 2003, 370, 1-181.

23. Mrkvička, J.; Veselá, M. Influence of fertilization rates on species composition, quality and yields of the meadow fodder. Rostl. Vyrob. 2002, 48, 494-498. [CrossRef]

24. Pavlů, V.; Hejcman, M.; Pavlů, L.; Gaisler, J.; Nežerková, P. Effect of continuous grazing on forage quality, quantity and animal performance. Agric. Ecosyst. Environ. 2006, 113, 349-355. [CrossRef]

25. Hrabě, F.; Knot, P. The effect of trophism level and exploitation intensityon the production characteristics of grassland community dominated by Festuca arundinacea Schreb. Plant Soil Environ. 2011, 57, 160-165. [CrossRef]

26. Štýbnarová, M.; Mičová, P.; Mrak-Fiala, P.; Karabcová, H.; Látal, O.; Pozdíšek, J. Effect of Organic Fertilizers on Botanical Composition of Grassland, Herbage Yield and Quality. Agric. Pol'nohospodárstvo 2014, 59, 87-97. [CrossRef]

27. Ludewig, K.; Donath, T.W.; Zelle, B.; Eckstein, R.L.; Mosner, E.; Otte, A.; Jensen, K. Effects of reduced summer precipitation on productivity and forage quality of floodplain meadows at the Elbe and the Rhine river. PLoS ONE 2015, 10, e0124140. [CrossRef]

28. Pornaro, C.; Basso, E.; Macolino, S. Pasture botanical composition and forage quality at farm scale: A case study. Ital. J. Agron. 2019, 14, 214-221. [CrossRef]

29. Schaub, S.; Finger, R.; Leiber, F.; Probst, S.; Kreuzer, M.; Weigelt, A.; Buchmann, N.; Scherer-Lorenzen, M. Plant diversity effects on forage quality, yield and revenues of semi-natural grasslands. Nat. Commun. 2020, 11, 768. [CrossRef]

30. Ranta, M.; Rotar, I.; Vidican, R.; Malinas, A.; Ranta, O.; Lefter, N. Influence of the UAN Fertilizer Application on Quantitative and Qualitative Changes in Semi-Natural Grassland in Western Carpathians. Agronomy 2021, 11, 267. [CrossRef]

31. Scotton, M.; Sicher, L.; Kasal, A. Semi-natural grasslands of the Non Valley (Eastern Italian Alps): Agronomic and environmental value of traditional and new Alpine hay-meadow types. Agric. Ecosyst. Environ. 2014, 197, 243-254. [CrossRef]

32. Loucougaray, G.; Dobremez, L.; Gos, P.; Pauthenet, Y.; Nettier, B.; Lavorel, S. Assessing the Effects of Grassland Management on Forage Production and Environmental Quality to Identify Paths to Ecological Intensification in Mountain Grasslands. Environ. Manag. 2015, 56, 1039-1052. [CrossRef] [PubMed]

33. Honsova, D.; Hejcman, M.; Klaudisova, M.; Pavlů, V.; Kocourkova, D.; Hakl, J. Species composition of an alluvial meadow after 40 years of applying nitrogen, phospohorus and potassium fertilizer. Preslia 2007, 79, 245-258.

34. Hrevušová, Z.; Hejcman, M.; Pavlů, V.; Hakl, J.; Klaudisová, M.; Mrkvička, J. Long-term dynamics of biomass production, soil chemical properties and plant species composition of alluvial grassland after the cessation of fertilizer application in the Czech Republic. Agric. Ecosyst. Environ. 2009, 130, 123-130. [CrossRef]

35. Vargová, V.; Kovačiková, Z.; Michalec, M. Effects of rates and nutrient ratios on production and quality of phytomass at fertiliser application to an alluvial meadow. Agriculture 2012, 58, 1-10. [CrossRef]

36. Hejcman, M.; Sochorová, L.; Pavlů, V.; Štrobach, J.; Diepolder, M.; Schellberg, J. The Steinach Grassland Experiment: Soil chemical properties, sward height and plant species composition in three cut alluvial meadow after decades-long fertilizer application. Agric. Ecosyst. Environ. 2014, 184, 76-87. [CrossRef]

37. Gillet, F.; Mauchamp, L.; Badot, P.-M.; Mouly, A. Recent changes in mountain grasslands: A vegetation resampling study. Ecol. Evol. 2016, 6, 2333-2345. [CrossRef]

38. Dindová, A.; Hakl, J.; Hrevušová, Z.; Nerušil, P. Relationships between long-term fertilization management and forage nutritive value in grasslands. Agric. Ecosyst. Environ. 2019, 279, 139-148. [CrossRef]

39. Kacorzyk, P.; Głab, T. Effect of ten years of mineral and organic fertilization on the herbage production of a mountain meadow. J. Elem. 2017, 22, 219-233. [CrossRef]

40. Buxton, D.R. Quality-related characteristics of forages as influenced by plant environment and agronomic factors. Anim. Feed Sci. Technol. 1996, 59, 37-49. [CrossRef]

41. Wilman, D.; Williams, S.P. A comparison of grass/white clover and grass silages offered to dairy cows as the sole feed. Grass Forage Sci. 1993, 48, 231-237. [CrossRef]

42. Lüscher, A.; Mueller-Harvey, I.; Soussana, J.F.; Rees, R.M.; Peyraud, J.L. Potential of legume-based grassland-livestock systems in Europe: A review. Grass Forage Sci. 2014, 69, 206-228. [CrossRef] [PubMed]

43. Schwinning, S.; Parsons, A.J. Interactions between grasses and legumes: Understanding variability in species composition. In Legumes in Sustainable Farming Systems, British Grassland Society Occasional Symposium No 30, Proceedings of Joint Conference of BGS and SFS Initiative, SAC, Craibstone, Aberdeen, 2-4 September 1996; Younie, D., Ed.; British Grassland Society (BGS) Hurley: Reading, UK, 1996; pp. 153-163.

44. Herben, T.; Mayerová, H.; Skálová, H.; Hadincová, V.; Pecháčková, S.; Krahulec, F. Long-term time series of legume cycles in a semi-natural montane grassland: Evidence for nitrogen-driven grass dynamics? Funct. Ecol. 2017, 31, 1430-1440. [CrossRef] 
45. Soons, M.B.; Hefting, M.M.; Dorland, E.; Lamers, L.P.M.; Versteeg, C.; Bobbink, R. Nitrogen effects on plant species richness in herbaceous communities are more widespread and stronger than those of phosphorus. Biol. Conserv. 2017, 212, 390-397. [CrossRef]

46. Galka, A.; Zarzynski, J.; Kopec, M. Effect of different fertilization regimes on species composition and habitat in a long-term grassland experiment. Grassl. Sci. Eur. 2005, 10, 132-135.

47. Socher, S.A.; Prati, D.; Boch, S.; Müller, J.; Klaus, V.H.; Hölzel, N.; Fischer, M. Direct and productivity-mediated indirect effects of fertilization, mowing and grazing on grassland species richness. J. Ecol. 2012, 100, 1391-1399. [CrossRef]

48. Allan, E.; Manning, P.; Alt, F.; Binkenstein, J.; Blaser, S.; Grassein, F.; Klaus, V.; Kleinebecker, T.; Morris, E.; Oelmann, Y.; et al. Land use intensification alters ecosystem multifunctionality via loss of biodiversity and changes to functional composition. Ecol. Lett. 2015, 18, 834-843. [CrossRef] [PubMed]

49. Humbert, J.-Y.; Dwyer, J.M.; Andrey, A.; Arlettaz, R. Impacts of nitrogen addition on plant biodiversity in mountain grasslands depend on dose, application duration and climate: A systematic review. Glob. Chang. Biol. 2015, 22, 110-120. [CrossRef]

50. Korevaar, H.; Geerts, R. Long-term effects of nutrients on productivity and species-richness of grasslands: The Ossekampen Grassland Experiment. In Proceedings of the Conference Valuing Long-Term Sites and Experiments for Agriculture and Ecology, Newcastle, UK, 27-28 May 2015; Peacock, S., Smith, B.M., Stockdale, E.A., Watson, C., Eds.; Association of Applied Biologists: Warwick, UK, 2015; Volume 128, pp. 253-256.

51. Müller, I.B.; Buhk, C.; Lange, D.; Entling, M.H.; Schirmel, J. Contrasting effects of irrigation and fertilization on plant diversity in hay meadows. Basic Appl. Ecol. 2016, 17, 576-585. [CrossRef]

52. Molina, C.D.; Tognetti, P.M.; Graff, P.; Chaneton, E.J. Mowing does not redress the negative effect of nutrient addition on alpha and beta diversity in a temperate grassland. J. Ecol. 2021, 109, 1501-1510. [CrossRef]

53. Hejcman, M.; Klaudisová, M.; Schellberg, J.; Honsová, D. The Rengen Grassland Experiment: Plant species composition after 64 years of fertilizer application. Agric. Ecosyst. Environ. 2007, 122, 259-266. [CrossRef]

54. John, H.; Dullau, S.; Baasch, A.; Tischew, S. Re-introduction of target species into degraded lowland hay meadows: How to manage the crucial first year? Ecol. Eng. 2016, 86, 223-230. [CrossRef]

55. Busch, V.; Klaus, V.H.; Schäfer, D.; Prati, D.; Boch, S.; Müller, J.; Chisté, M.; Mody, K.; Blüthgen, N.; Fischer, M.; et al. Will I stay or will I go? Plant species specific response and tolerance to high land-use intensity in temperate grassland ecosystems. J. Veg. Sci. 2019, 30, 674-686. [CrossRef]

56. Grime, J.P. Plant Strategies and Vegetation Processes; Wiley \& Sons: New York, NY, USA, 1979; ISBN 9780471996927.

57. Hautier, Y.; Niklaus, P.A.; Hector, A. Competition for light causes plant biodiversity loss after eutrophication. Science 2009, 324, 636-638. [CrossRef]

58. Schubert, R. Prodromus der Pflanzengesellschaften Sachsen-Anhalts. Mitt. Florist. Kart. Sachsen-Anhalt 2001, 2, 1-688.

59. Burkart, M. River corridor plants (Stromtalpflanzen) in Central European lowland: A review of a poorly understood plant distribution pattern. Glob. Ecol. Biogeogr. 2001, 10, 449-468. [CrossRef]

60. Jäger, E.J. (Ed.) Rothmaler_Exkursionsflora von Deutschland. Gefäßpflanzen: Grundband, 21st ed.; Springer Spektrum: Berlin, Germany, 2017; ISBN 978-3-662-49707-4.

61. Deutsches Institut für Normung. DIN ISO 10390:2005-02 Soil quality—Determination of pH; Beuth: Berlin, Germany, $2005 ;$ p. 7.

62. Deutsches Institut für Normung. DIN 51721:2001-08 Testing of Solid Fuels-Determination of Carbon Content and Hydrogen ContentRadmacher-Hoverath Method; Beuth: Berlin, Germany, 2001; p. 5. [CrossRef]

63. Deutsches Institut für Normung. DIN 51722-1:1990-07 Testing of Solid Fuels; Determination of Nitrogen Content; Semi-Micro Kjeldahl Method, Beuth: Berlin, Germany, 1990; p. 7. [CrossRef]

64. VDLUFA. Methodenbuch der VDLUFA Band I. Die Untersuchung von Böden, 4th ed.; Verband Deutscher Landwirtschaftlicher Untersuchungs-und Forschungsanstalten (VDLUFA): Darmstadt, Germany, 1991; ISBN 978-3-941273-13-9.

65. Landesanstalt für Landwirtschaft und Gartenbau Sachsen-Anhalt (LLG). Richtwertsammlung Düngerecht, Abgestimmt mit den Ländern Brandenburg, Mecklenburg- Vorpommern, Sachsen und Thüringen- Gültig für Sachsen-Anhalt. Teil 2. Tabellen 9-15; Landesanstalt für Landwirtschaft und Gartenbau Sachsen-Anhalt: Halle (Saale), Germany, 2019. Available online: https://1lg.sachsen-anhalt.de/ fileadmin/Bibliothek/Politik_und_Verwaltung/MLU/LLFG/Dokumente/04_themen/pfl_ernaehr_duengung/Richtwerte/ 2019_rw_teil5_duengerecht.pdf (accessed on 14 December 2020).

66. Londo, G. The decimal scale for releves of permanent quadrats. Vegetatio 1976, 33, 61-64. [CrossRef]

67. Voigtländer, G.; Voss, N. Methoden der Grünlanduntersuchung und -Bewertung. Grünland, Feldfutter, Rasen; Ulmer: Stuttgart, Germany, 1979; ISBN 9783800130436.

68. VDLUFA. Methodenbuch der VDLUFA Band III. Die Chemische Untersuchung von Futtermitteln, 3rd ed.; Verband Deutscher Landwirtschaftlicher Untersuchungs-und Forschungsanstalten (VDLUFA): Darmstadt, Germany, 2004; ISBN 978-3-941273-14-6.

69. Losand, B.; Pries, M.; Menke, A.; Tholen, E.; Gruber, L.; Hertwig, F.; Jilg, T.; Kluth, H.; Spiekers, H.; Steingaß, H.; et al. Schätzung des Energiegehaltes in Grasprodukten-Bericht zum Stand neuer Ableitungen. In Proceedings of the Forum angewandte Forschung in der Rinder- und Schweinefütterung, Fulda, Germany, 28-29 March 2007; pp. 105-109.

70. Schuboth, J.; Frank, D. Kartieranleitung Lebensraumtypen Sachsen-Anhalt. Teil Offenland. Zur Kartierung der Lebensraumtypen nach Anhang I der FFH-Richtlinie; Landesamt für Umweltschutz Sachsen-Anhalt: Halle (Saale), Germany, 2010. 
71. Grime, J.P.; Hodgson, J.G.; Hunt, R. Comparative Plant Ecology. A Functional Approach to Common British Species; Unwin Hyman: London, UK, 1988; ISBN 978-0-412-74170-8.

72. R Development Core Team. R: A Language and Environment for Statistical Computing; R Foundation for Statistical Computing: Vienna, Austria, 2021. Available online: http:/ / cran.r-project.org (accessed on 8 January 2021).

73. Bates, D.; Mächler, M.; Bolker, B.; Walker, S. Fitting linear mixed-effects models using lme4. J. Statist. Softw. 2015, 67, 1-48. [CrossRef]

74. Warton, D.I.; Hui, F.K.C. The arcsine is asinine: The analysis of proportions in ecology. Ecology 2011, 92, 3-10. [CrossRef]

75. Crawley, M.J. The R book, 2nd ed.; Wiley \& Sons: Chichester, UK, 2013; ISBN 978-0-470-97392-9.

76. Bayerische Landesanstalt für Landwirtschaft (LfL). Gruber Tabelle zur Fütterung der Milchkühe, Zuchtrinder, Mastrinder, Schafe, Ziegen; LfL-Informationen Freising-Weihenstephan, Bayerische Landesanstalt für Landwirtschaft: Freising, Germany, 2019.

77. Ineichen, S.; Marquardt, S.; Kreuzer, M.; Reidy, B. Forage quality of species-rich mountain grasslands subjected to zero, PK and NPK mineral fertilization for decades. Grass Forage Sci. 2020, 75, 385-397. [CrossRef]

78. Schellberg, J.; Möseler, B.M.; Kühbauch, W.; Rademacher, I.F. Long-term effects of fertilizer on soil nutrient concentration, yield, forage quality and floristic composition of a hay meadow in the Eifel mountains, Germany. Grass Forage Sci. 1999, 54, 195-207. [CrossRef]

79. Larter, N.; Nagy, J.A. Seasonal and annual variability in the quality of important forage plants on Banks Island, Canadian High Arctic. Appl. Veg. Sci. 2001, 4, 115-128. [CrossRef]

80. Blöschl, G.; Kiss, A.; Viglione, A.; Barriendos, M.; Böhm, O.; Brázdil, R.; Coeur, D.; Demarée, G.; Llasat, M.C.; Macdonald, N.; et al Current European flood-rich period exceptional compared with past 500 years. Nature 2020, 583, 560-566. [CrossRef]

81. Peters, A.; Filley, S.; Hulting, A. Forage Value of Pasture Weeds in Southwestern Oregon; Beef Research Report 2010; Oregon State University: Corvallis, OR, USA, 2010; Volume 26, p. 6.

82. Pannach, H.; Biosphere Reserve Mittelelbe, Dessau, Germany. Personal Communication. 2021.

83. Kidd, J.; Manning, P.; Simkin, J.; Peacock, S.; Stockdale, E. Impacts of 120 years of fertilizer addition on a temperate grassland ecosystem. PLoS ONE 2017, 12, e0174632. [CrossRef]

84. Witwicki, D.L.; Munson, S.M.; Thoma, D.P. Effects of climate and water balance across grasslands of varying C3 and C4 grass cover. Ecosphere 2016, 7, e01577. [CrossRef]

85. Güsewell, G. Responses of wetland graminoids to the relative supply of nitrogen and phosphorus. Plant Ecol. 2005, 176, 35-55. [CrossRef]

86. Oelmann, Y.; Broll, G.; Hölzel, N.; Kleinebecker, T.; Vogel, A.; Schwartze, P. Nutrient impoverishment and limitation of productivity after 20 years of conservation management in wet grasslands of north-western Germany. Biol. Conserv. 2009, 142, 2941-2948. [CrossRef]

87. Pavlů, V.; Gaisler, J.; Pavlů, L.; Hejcman, M.; Ludvíková, V. Effect of fertiliser application and abandonment on plant species composition of Festuca rubra grassland. Acta Oecol. Montrouge 2012, 45, 42-49. [CrossRef]

88. Ringselle, B.; De Cauwer, B.; Salonen, J.; Soukup, J. A Review of Non-Chemical Management of Couch Grass (Elymus repens). Agronomy 2020, 10, 1178. [CrossRef]

89. Schwinning, S.; Parsons, A.J. Analysis of the co-existence mechanisms for grasses and legumes in grazing systems. J. Ecol. 1996, 84, 799-813. [CrossRef]

90. Pavlů, V.; Schellberg, J.; Hejcman, M. Cutting frequency vs. N application: Effect of a 20-year management in Lolio-Cynosuretum grassland. Grass Forage Sci. 2011, 66, 501-515. [CrossRef]

91. Holúbek, I.; Petrovič, F. An economic analysis of permanent and oversown grasslands based on the data from research experiments. Ekológia 2011, 30, 122-132. [CrossRef]

92. Hopkins, A.; Holz, B. Grassland for agriculture and nature conservation: Production, quality and multi-functionality. Agron. Res. 2006, 4, 3-20.

93. Weggler, K.; Thumm, U.; Elsaesser, M. Development of Legumes After Reseeding in Permanent Grassland, as Affected by Nitrogen Fertilizer Applications. Agriculture 2019, 9, 207. [CrossRef]

94. Opitz, V.; Boberfeld, W.; Laser, H. Einfluss von Lotus corniculatus auf die Nutzungselastizität bestandsprägender Gräser der Extensiv-Weiden (Effect of Lotus corniculatus on the elasticity of forage utilization of dominant grass species in extensive pastures). Pflanzenbauwissenschaften 1999, 3, 88-93.

95. Raus, J.; Knot, P.; Skládanka, J.; Kvasnovský, M.; Sochorec, M.; Mejía, J.E.A.; Hrabě, F. Effect of Cutting Pattern and Fertilization Level on Species Diversity and Evaluation of Grassland Quality. Acta Univ. Agric. Silvic. Mendel. Brun. 2014, 62, 1087-1093. [CrossRef]

96. Beltman, B.; Willems, J.H.; Güsewell, S. Flood events overrule fertiliser effects on biomass production and species richness in riverine grasslands. J. Veg. Sci. 2007, 18, 625-634. [CrossRef]

97. Tallowin, J.; Jefferson, R. Hay production from lowland semi-natural grasslands: A review of implications for ruminant livestock systems. Grass Forage Sci. 2008, 54, 99-115. [CrossRef]

98. Kirkham, F.W.; Tallowin, J.R.B.; Dunn, R.M.; Bhogal, A.; Chambers, B.J.; Bardgett, R.D. Ecologically sustainable fertility management for the maintenance of species-rich hay meadows: A 12-year fertilizer and lime experiment. J. Appl. Ecol. 2014, 51, 152-161. [CrossRef] 
99. Van Dobben, H.F.; Wieger Wamelink, G.W.; Slim, P.A.; Kamiński, J.; Piórkowski, H. Species-rich grassland can persist under nitrogen-rich but phosphorus-limited conditions. Plant Soil 2017, 41, 451-466. [CrossRef]

100. Dickson, T.L.; Mittelbach, G.G.; Reynolds, H.L.; Gross, K.L. Height and clonality traits determine plant community responses to fertilization. Ecology 2014, 95, 2443-2452. [CrossRef] 